\title{
THE DECLINE OF THE PRINTED \\ CATALOGUE IN BRITAIN
}

\author{
By J. H. BOWMAN \\ University College London
}

In the nineteenth century British public library catalogues were invariably printed, and sold in the form of a book. They were usually dictionary catalogues, with author, title and subject entries interfiled in a single alphabetical sequence. During the I890s controversy began to rage regarding the benefits of such catalogues, and gradually classified catalogues began to appear alongside them. By the end of the nineteenth century other physical forms, cards or slips, were appearing, initially as supplements to printed catalogues and then replacing them. After I9I8 the increased cost of printing accelerated their decline, so that by the late I930s printing was practically reserved for lists of new accessions. A very few authorities continued with printed catalogues after 1945, and there was a brief resurgence in the I96os due to computerization. The appearance of the online catalogue in the I980s ultimately spelt the end of all other physical forms.

In the early days of 'free' public libraries it was normal to provide a printed catalogue of the stock. ${ }^{1}$ The printed catalogue had earlier been the normal form of catalogue for university libraries and for others such as the British Museum, but its inflexibility meant that in many cases it was replaced by the guard-book, where the entries were printed singly and pasted on to loose-leaf pages, leaving gaps for subsequent insertions. In the United States it is clear that the printed catalogue had all but died out by the end of the nineteenth century. ${ }^{2}$ There were two reasons for this: the increasing size of libraries meant that it was no longer feasible to keep producing printed catalogues; and the desire to include helpful extra information about the items caused the catalogues to become too bulky and expensive. The final blow was dealt in I90I when the Library of Congress began to sell printed catalogue cards, which meant that every library had the facility to acquire good quality records for its own catalogue. ${ }^{3}$

In Britain the position was very different. When public libraries were established under the Public Libraries Act of I850 the stock (with the occasional exception of a small number of reference books) was invariably on closed access. ${ }^{4}$ This meant that readers had to ask for the book they wanted to see, and in order to do this they had to have a catalogue. In the early days the catalogue always took the form of a printed book which, as well as being available in the library itself, was offered for sale. At this time there seems to have been no suggestion that any other physical form of catalogue was possible. In this sense the library catalogue was just like any other trade catalogue (except that it was charged for): the supplier issued it in printed form for potential customers.

Address correspondence to: Dr J. H. Bowman, School of Library, Archive and Information Studies, University College London, Gower Street, LondonwCIE 6вт, UK; e-mail: j.bowman@ucl.ac.uk 


\section{Different forms of printed catalogues}

The physical form of a catalogue is called its 'outer' form, but we cannot look at the history of the printed catalogue without including a debate which raged for many years over its 'inner' form, namely its arrangement on the 'dictionary' or 'classified' principle. 'Dictionary' is a rather unhelpful term in this context, because its meaning, as Barrett pointed out when the debate began, is not self-evident. ${ }^{5}$ A dictionary catalogue contains entries under author, title and subject, all interfiled in a single sequence. There can be variations in the manner in which this is done, which will be discussed below, but this is its essence. A classified catalogue on the other hand is arranged by subject, nowadays usually by means of a classification scheme. To serve readers looking for specific authors or works a classified catalogue must have an index of authors, and possibly one of titles; and of course if the arrangement is according to a classification scheme there must be a subject index to that scheme.

In the early part of the nineteenth century it was quite normal for printed catalogues to be of the classified kind, but they were not as they are now. 'Classed' was perhaps the more usual term, and these catalogues were arranged according to a small number of very broad subjects, with some further simple subdivision. During the second half of the century, however, the trend moved in favour of dictionary catalogues; Norris indeed concludes her history at the rise of the dictionary catalogue. ${ }^{6}$ It is surely significant that this period coincides with the rise of the public libraries, which almost invariably had dictionary catalogues. Quinn believed that the first catalogue truly to follow dictionary principles was that produced for Liverpool by Samuel Huggins in I872. In I89I James Duff Brown could write: 'The one point about which most librarians are agreed on this subject is the superiority of the dictionary or single alphabetical form of arrangement." Yet within a few years he had become highly critical of them, and before long he was one of their chief opponents. 9

In the mid-I890s the classified catalogue reappeared, and seems to have been regarded by public librarians, who probably knew nothing of its antecedents, as an innovation. ${ }^{10}$ Jast describes its parts: (I) catalogue proper; (2) index of subjects. These were absolutely essential, and it was desirable to have also (3) index of authors; (4) table of classification. Additionally one might have a title index for fiction. He refers to the 'old type of classified catalogue', where there was no alphabetical index, and the only way to find a specific subject was to search through the table of classification. ${ }^{11}$ It is not surprising that the dictionary catalogue was welcomed by a public which had had to put up with such inconvenience, and the fact that it was an improvement must have been a major cause of its popularity. It is also clear from the way in which they wrote about it that the new public librarians felt that the dictionary form was easier for the general public to use. The prevalence or otherwise of the dictionary catalogue in Britain has been somewhat misunderstood. Pettee, for example, states, 'In England the dictionary catalog has never been popular'. ${ }^{12}$ This, as I shall show, is quite untrue.

From the I 890 s the question of the superiority of the dictionary or classified catalogue was keenly debated by public librarians, and initially this was independent of whether it was printed. Curran read a paper on the topic at the annual meeting of the Library Association in $1894,{ }^{13}$ and at the same meeting Jast brought the subject into his paper on classification. ${ }^{14} \mathrm{He}$ accuses the dictionary catalogue of 'sham simplicity'; it appeals to the 
general reader because it appears to require no special understanding. It is also easier to make a good dictionary than a good classified catalogue. Errors pass unnoticed more easily. He likens the dictionary catalogue to an index and the classified to a map, 'by which the whole "lie" of the library contents may be seen at a glance'.

The anonymous reviewer of various published catalogues received by The Library in I895 noticed that there was an increasing proportion in favour of the 'old-fashioned classified catalogue'. ${ }^{15}$ The same observation was made by Jast, who in I896 addressed the annual conference of the Library Association on the question of class-lists. He cites the increasing proportion of catalogues reviewed in The Library as being class-lists: from one out of five in 1893 to twelve out of twenty-four in 1895 . The principle of the dictionary catalogue was, he said, 'inherently bad', and he extols the virtues of the class-list, which are mainly variations on the theme that the whole library does not have to be catalogued at once. ${ }^{16}$

Naturally the subject was discussed at the Second International Library Conference in I897, at which F. T. Barrett of the Mitchell Library, Glasgow, read a paper. ${ }^{17}$ He tried to discuss the matter impartially, particularly because some previous participants in the controversy had used 'heated language', and it is worth looking at this at some length because many of his arguments recur in the later discussion. He states that the purpose of the catalogue is to guide the public 'by the shortest and simplest route to whatever they desire at the moment of reference'. He dismisses one of the advantages often claimed for the classified catalogue, namely that it can be issued in sections: the same can be done with the alphabetical catalogue, and he cites Birmingham and Wigan as examples. (Nevertheless one wonders at the usefulness of an alphabetical catalogue issued in sections. Readers would presumably wish to acquire the whole, whereas the advantage of the classified was that they could purchase just the portion that interested them.) Barrett discusses the different ways in which readers use a catalogue, depending on whether they are looking for a specific book, or books by a specific author, or just browsing for something to read. In his experience the most common request is for books on a particular subject. This, he maintains, is most easily satisfied by means of the alphabetical catalogue, because it avoids reference from one place to another. As in most of these discussions, there is no mention of the difficulty of synonyms, or of the fact that many closely related subjects will be in quite different parts of the alphabet. The dictionary catalogue also satisfies most easily those readers who are looking for all the works of a person. In the classified catalogue this can be achieved only by looking up each reference from the author index, and the reader is unlikely to know where to start.

Turning to the classified catalogue he mentions the advantage already alluded to, namely that readers can purchase just one section. He counters this with the interesting argument that they ought to be made aware of the existence of other subjects apart from those of their own special interest. Secondly, there may be some advantage, in open access libraries, in having the catalogue in the same order as the shelves. The main advantage of the classified catalogue is economy, because a brief catalogue without indexes can be produced more cheaply than a dictionary catalogue. Finally he gives his opinion that $80 \%$ of enquiries can be answered at first reference in a dictionary catalogue, whereas in a classified catalogue not more than Io\% of readers would be able to find what they wanted at the first entry. He concludes in favour of the dictionary catalogue. 
At about the same time W. E. Doubleday examined the problem. He felt that the dictionary catalogue had been falsely accused on the basis of some bad examples. He admits that the class-list has several advantages: it means that the whole of the library does not have to be catalogued at once; and it is possible for readers to buy just the portion that interests them. He also concedes some of the difficulties of dictionary catalogues, in particular the cost. One of the frequent criticisms of dictionary catalogues is inconsistency, but this objection could be made of any catalogue. However, in his experience few readers want only a narrow range of subjects. And if they are interested in a specific author, such as Ruskin, they have to look at various different places in the catalogue. Not surprisingly, in trying to be dispassionate, Doubleday does not come to a definite conclusion about the matter. ${ }^{18}$

By the end of the decade it is apparent that a shift was taking place. In I899 Quinn mentions that even librarians who had an 'unbounded belief' in the benefits of the dictionary catalogue were being compelled to adopt the classified because otherwise their catalogues became too large. ${ }^{19}$ Jast too, returning to the subject, reiterated his opinion that the popularity of the classified catalogue, chiefly in the form of sectional lists, was daily increasing. ${ }^{20}$ Until recently, he says, no one thought to consider the matter, because it was regarded as settled in favour of the dictionary catalogue. He meets head-on the common objection that in a classified catalogue the user has inevitably to refer from an index to the entry itself. 'Is there no such thing in a dictionary catalogue as the necessity of reference from one place to another then? Take a subject like Zoology, or even a subdivision of it, and you may have to refer to twenty, to thirty, places before you have gathered the material into your net. One reference in a class list suffices.' As far as subject searches are concerned, the classified catalogue is superior, and as regards authors, the loss of time is only slight. Like some of Jast's other statements we must be careful of taking his assertion of increasing popularity at its face value, and it is likely that he exaggerated in line with his own wishful thinking.

William Plant of Shoreditch Public Libraries read a paper to a meeting of the Society of Public Librarians in April ı899. He saw the chief objection to the dictionary catalogue as being the requirement to make the subject headings as specific as possible, rather than grouping a number of topics under one broader heading. He advocated a two-part catalogue: one part being an author and title list, and the other classified, but omitting fiction. ${ }^{21}$ A little later, James Duff Brown, who had by now changed his mind, advocated the classified catalogue on the grounds that $90 \%$ of readers were not looking for books by particular authors, but wanted something on a specific subject. ${ }^{22}$

William Willcock, Librarian of Peterborough, outlined the requirements for a good index to a classified catalogue, suggesting that the author index should always give the section of the catalogue followed by the brief subject. ${ }^{23}$ This would produce entries such as:

DARWIN, C. Botany, 37. Evolution, 33. Geology, 34.

This would solve the problem of meaningless bare page-numbers, while not increasing the bulk of the catalogue out of proportion to its usefulness.

A more international perspective was provided by Henry Bond, Librarian of Lincoln, who had compared some British and American catalogues and found the British wanting. ${ }^{24} \mathrm{He}$ also attempted an objective comparison of the two types, basing his argument on the ideal printed catalogue in each case, and attempting to answer the questions: 
I. Which is the more logical and educative arrangement?

2. Which forms the more ready reference to the contents of a library?

3. Which is the more economical?

In the case of the classified catalogue he recognized several kinds, according to the number of indexes provided. The answer to the first question was undoubtedly the classified, because it brought related subjects together in a logical order. To the second, the answer was equally undoubtedly the dictionary, because more searches would be successful at the first attempt, without the need to follow cross-references. As for economy, the answer depended on how many indexes were provided for a classified catalogue; if very few, the classified was cheaper. The result of all this was to lead Bond to suggest that neither catalogue was inherently superior and that there could therefore be no consensus. He concludes with the observation that if the questions were considered again in relation to a card or manuscript catalogue instead of printed then the disadvantages of the classified arrangement would be magnified, and consequently the dictionary would be superior.

If by saying that there could be no consensus he expected to put an end to the debate Bond was mistaken. The annual meeting of the Library Association in I90I included two papers on the subject: J. Henry Quinn, Librarian of Chelsea, supported the classified catalogue, and W. E. Doubleday, Librarian of Hampstead, the dictionary. Quinn admits that he is being asked to defend an unpopular cause, but nevertheless says that the classified catalogue is gradually supplanting the dictionary. ${ }^{25} \mathrm{He}$ refers to the oft-quoted justification of the dictionary catalogue, that it appealed to the general reader and was easily understood. The reality of the matter was that it was easy to compile. 'Should a book present some difficulty by reason of the variety or complex nature of its contents, it is got rid of by means of an author- and possible title-entry, and no one is the wiser.' As for the antipathy to the classified catalogue, this dated from the early days of public libraries, when such catalogues simply lumped together hundreds of titles under broad headings without subdivision. He counters the argument that it is difficult in a classified catalogue to find all the books by a particular author by saying that this is easily solved with an author-title index. A classified catalogue has the added advantage that it could be published in instalments as a series of class-lists. He concludes by saying that with the spread of education and the consequent increasing knowledge of books it would necessary to have a much more systematic description of the contents of libraries in the future.

Doubleday again defended the dictionary catalogue. ${ }^{26}$ He agreed, however, that for students the classified catalogue was better, and that in open access libraries catalogues were of less importance than in other libraries. Nevertheless the dictionary catalogue was the best suited for all kinds of readers, because the classified assumed that readers were specialists. To use a classified catalogue effectively the reader had to understand the system, which might require considerable study. He also cites examples of obscure titles, of which the classified catalogue would require that the reader knew the subject: Eothen, Human Intercourse, Unto this Last, and Past and Present. Moving on to other points he refutes the assertion that dictionary catalogues would simply become impossible as libraries became larger. Limitations of space would prevent this, as it would always be necessary to have periodic 'clearances' of stock. As for the relative costs, it is likely that the classified is considerably cheaper, but this is at the expense of readers' 
time, who will often have to look something up more than once before finding it. He finishes, however, by saying that he would be quite willing to change his mind if someone could come up with a better solution.

W. C. Plant repeated his suggestion of combining the best aspects of both kinds of catalogue. ${ }^{27}$ He gives rather more detail than most in describing the difficulties of the classified catalogue, relating them particularly to the use of classification schemes, such as Dewey. Someone looking for material on marriage would have to look at 392, 265 and $\mathrm{I} 73$, depending on the point of view from which he approached the subject. In local history the position was even worse: for Shoreditch, for example, he would have to look at $239,346,352,36 \mathrm{I}, 377$ and 932, whereas in a dictionary catalogue all these would have an entry under Shoreditch. He noted that some of the features of the classified catalogue had been introduced into the dictionary, so that under broad headings like Africa various sub-headings were also found. He proposes taking this further, and seems to be suggesting something like what later became known as the alphabetico-classed catalogue. In the ensuing discussion C. W. F. Goss of the Bishopsgate Institute spoke strongly in favour of the dictionary catalogue. ${ }^{28} \mathrm{~W}$. S. C. Rae, Librarian of Darwen, favoured the classified catalogue, issued in class sections, because it had the advantages of cheapness, completeness and adaptability, but particularly because it allowed the library to popularize whole classes of literature. ${ }^{29}$

To return to the outer form, we can obtain evidence of the extent of use of the various types of catalogue from Greenwood's library year book and its successors, together with the Literary year-book. ${ }^{30}$ The first edition of Greenwood appeared in I897, and contained 33I entries, though at least a third of these have no information about catalogues, usually because the library in question had not yet opened. Of the libraries for which information is given only one does not have a printed catalogue; this library (St Giles \& St George, Holborn) has a manuscript catalogue in guard-books. Several libraries use other formats for supplements, the commonest being 'manuscript cards' or slips. No doubt many others did the same but did not record the fact, for such supplements must have been regarded as temporary expedients only, prior to the production of a revised printed catalogue.

As for the inner form, the majority are dictionary, though there is a scattering of both author and classified catalogues. A few have classified catalogues only. ${ }^{31}$ In some cases different forms were adopted in the reference and lending library; an example is Aston Manor, Birmingham, where the reference library had a dictionary catalogue but the lending was in class-lists. None of the libraries shown as having a classified catalogue at this time was using a systematic classification scheme, which means that they must all have been based on 'main classes', and so were not at all what we should now think of as a 'classified' catalogue. This is significant because it shows that classified catalogues were not simply an outcome of using classification schemes. ${ }^{32}$

Looking at the next edition of the year book (I900/OI) we can begin to detect a slight change as far as physical form is concerned. Here three libraries, Limerick, Moss Side and Queenborough, are shown as having manuscript catalogues only, but in each case they had no catalogue at all in the previous edition, and so we must assume that the catalogues were in course of preparation. On the other hand, many of the libraries which previously had only printed catalogues are now shown as having cards or slips also; sometimes it is specifically stated that these are supplementary. Interestingly Aston 
Manor, which in I897 had had class-lists for its lending library, in I906 issued a catalogue 'arranged on the dictionary plan'. ${ }^{33}$ The preface draws attention to the new format, justifying it 'on the ground that, while the works on any given subject may still be found grouped together, and, in fact, a much larger number of grouped entries appear in this than in any previous edition of the Catalogue-all the works of a given author, and all works on a given subject (although belonging to different classes), are brought together and may be seen at a glance'. This change casts doubt on Jast's assertion that the classified catalogue was gaining ground, and evidence from the I900/or year book provides little corroboration of his statement: if the entries are to be believed, about a dozen had changed from dictionary to classified, or had added a classified catalogue, but about half a dozen had moved in the opposite direction. As a proportion of the total this seems insignificant.

In I908 Brown devoted another article to 'The tyranny of the catalogue'. ${ }^{34} \mathrm{He}$ maintained that the prestige attached to the dictionary catalogue had hindered the progress of systematic classification in Britain, but he does not really prove a relationship. He also states that it is a bar to progress in that it tends to produce identical stocks in different libraries. No evidence is given, and surely if this was true at all it would be true of any kind of catalogue; it is the fact that the catalogue is printed and thus easily portable that is relevant, rather than its dictionary form. He surveyed a sample of printed catalogues and concluded that considerable proportions of them consisted of stock which, because it was out of date, should not have been in the catalogue at all; in one case this proportion was as high as $60 \%$. Again it is hard to know what criteria he applied, apart from age, and his decisions were clearly very subjective. His conclusion is that the printed catalogue should contain only 'live' books, and that the complete catalogue should be in manuscript form. Considering that one would expect new stock to be the most 'live' of all, this suggestion seems rather impractical.

Nevertheless, by this time we can begin to see an increase in libraries which had 'manuscript' catalogues as well as printed. The Literary year-book for I9I3 shows an increase in the number of libraries with either sheaf or card catalogues only, ${ }^{35}$ together with a significant number of libraries continuing to use a printed catalogue for the lending stock but using cards or slips for the reference collections. This kind of division does not seem to be mentioned in contemporary accounts, but it can presumably be attributed to the fact that it was less necessary to be able to take the reference collection catalogue off the premises.

Open access continued to make progress, so that in due course the continuing debate came to be related specifically to open access libraries. The question was debated at a meeting of the Library Assistants' Association in I9I0, both speakers restricting themselves (unusually) to the physical form. James Young supported the printed catalogue, on the grounds that even in an open access library it was necessary to know about books that were out as well as those that were in, and that only the printed catalogue allowed this to happen regardless of whether the library was open or closed. The printed catalogue had a missionary role, as it could inform the public of the library's contents without their visiting the library. 'Common sense and the spirit of the age will both cry for the modern librarian to issue a printed catalogue.' Moreover, it seemed natural that the guide to a collection of books should itself be another book. A card catalogue was difficult to use because of the number of other users. As for the cost, 'much of the initial 
outlay' would be recouped by sales. He concludes by again emphasizing the missionary aspect: 'Quietly and unobtrusively it finds it way everywhere, infallibly carrying the message from the library to the people. ${ }^{36}$

Sayers spoke against printed catalogues. He admitted that in the Utopian library there would be a printed catalogue, but it would be reprinted every two or three months; it would also be classified. He admits that the printed catalogue is convenient and the sequence of entries is clear, but he questions how many readers actually buy one, reckoning that it is not more than $5 \%$. In open access libraries the catalogue has little appeal, and the expense of a printed one is not justified. He advocates manuscript catalogues, either sheaf or card..$^{37}$

In I9ro Brown was able to put into practice his theory that the catalogue should contain live books only: he published what was greeted as the first of a new kind of printed catalogue, a Select catalogue and guide for Islington Libraries. ${ }^{38}$ This was welcomed by Jast, who noted that the attitude of public librarians towards the catalogue had been gradually changing and saw this as marking 'the definite beginning of a new epoch'. Now that open access was increasing in popularity it was less necessary to provide a complete catalogue, and in fact could be counterproductive as the amount of material included might well frighten people away (why this should suddenly be a problem with open access is unclear). Moreover, the increasing role that libraries were playing in education meant that a selective catalogue was of far more use. ${ }^{39}$ The remaining stock, that which was not 'select', was included in a complete manuscript catalogue. ${ }^{40}$ An interesting incidental feature of this printed catalogue was that if a subject covered a range of numbers in the classification scheme only the range was used in the heading; shelf-marks are not shown for the individual books. G. T. Shaw, Librarian of Liverpool, also saw open access as in some ways a substitute for a printed catalogue. He had no intention of printing catalogues for his open access branches, and if he had to do so the open access system would have failed. He reckoned that he would not sell 500 copies of a branch catalogue in two years. ${ }^{41}$

Considering that feeling seemed to be running against the printed catalogue it is slightly surprising that in I9I0 Alex Philip chose to publish the only book solely devoted to its production. ${ }^{42}$ He doubts whether the saving made by producing only a selective catalogue is worth the uncertainty which this causes in borrowers' minds when they know the catalogue to be incomplete. ${ }^{43}$ For all the reasons which we have already seen, he advocates the complete printed catalogue.

By I9I4 Brown could say, with typical exaggeration, that open access was 'thoroughly established as part of the policy of nearly every public library of importance'. ${ }^{44}$ At the same time the dictionary catalogue continued to decline. McGill and Coutts state that it is unsuited to open access 'because it follows an arrangement different from that of the books on the shelves'; ${ }^{45}$ a strange argument, which has not been repeated. The matter was by no means settled, however, and in I9I4 William Lillie, of Middlesbrough, discussed the relative merits of dictionary and classified catalogues in relation to Cutter's well-known 'objects of the catalogue', and gave the usual advantages and disadvantages. ${ }^{46}$ The classified form is undoubtedly more logical and educative, and of great value for someone studying a special subject, but requires considerable study before it can be understood. A particular advantage of the dictionary catalogue arises in searching for books about a person. Dr Livingstone is given as an example of someone who would 
be very difficult to find in a classified catalogue because his name is connected to so many different subjects. Having discussed the pros and cons, Lillie does not actually reach a conclusion.

Bond, in a general survey of practice in 1915 , stated that although the classified catalogue had increased in popularity this increase had levelled off, and about half of recently published catalogues still used the dictionary format. ${ }^{47}$ In I9I6 the Library World remarked on the decline of the printed catalogue, saying that 'the important catalogues of municipal libraries can be counted on the fingers of two hands' $;^{48}$ this indicates that by this time the reduction in the printed form must have been considerable.

\section{Characteristics of the dictionary catalogue}

It is time to look at what a typical dictionary catalogue contained. We need to consider two aspects: the entry points and the description, and, as so often, they are intertwined. We have already seen that a dictionary catalogue contains entries under author, title and subject. Usually the first of these presented no problem, except that there might be a special rule for dealing with anonymous works. Opinions also differed on whether pseudonyms or real names should be used as the entry point. Practice concerning joint authors varied: the second author might have no entry, a cross-reference, or a fairly full entry. There were occasional comments on abnormal entry points, such as saints being entered under 'Saint ...' by Bromley and Willesden in catalogues issued in $1894 .{ }^{49}$

As for title and subject, these are frequently the same thing. If the title of the book contained words which adequately expressed its subject, these words would be brought to the front to provide the entry point, the remainder being inverted after them. In these cases there would not normally be a separate entry under the title proper as we should understand it, because the assumption was that the reader would find it by the principal words. Figure I shows several examples of this, including inconsistent treatment, as at Isaiah, where the order of the inverted words varies.

Sometimes this kind of inversion provoked criticism. For example, the reviewer of a catalogue issued in 1903 by Shrewsbury Free Library commented on the entry:

French, Surname of, in England, County Records of the, Iroo-I350, by A. D. Weld French

saying that it would 'puzzle anyone to know what the title of the book really is'..$^{50}$ Ogle too complained of ugly inversions in titles to produce subject entries, and cites the following examples: ${ }^{51}$

Cevennes. Travels of a donkey in the, R. L. Stevenson.

Great Britain and Ireland. Handbook to, by R. Allbut.

Jubal, Legend of, and other Poems, by G. Eliot.

He also disliked the use of the dash to repeat the previous heading, which was very common in these catalogues, and states that the dash should be used only for the first word, and not repeated as in the following:

Journal of a Cavalry Officer.

- - - Home Life.

- _ March from Delhi. 
190

\section{Ireland-Isle}

Ireland, Collection of Tracts and Treatises on, continued-

Date

Vol. 2, Political Anatomy of Ireland, by Sir W. Petty, 1672; The Querist, and a Word to the Wise, by Bp. Berkeley, 1752 ; List of Absentees and their Incomes spent abroad, 1729 and 1769 ; Trade and Improvement of Ireland, by A. Dobbs, 1729;

Number of Protestant and Popish Families in Ireland, 1732-3.

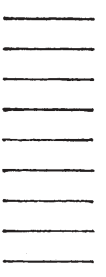

Historical Songs of (Percy Society,

- 1 8ro 1840

Inland Navigation of (Parliamentary Reports, $)$ 1811-15. $\quad . \quad$. 1 fol

in 1825 ( $\left.\begin{array}{c}\text { Parliamentary } \\ \text { Keports. }\end{array}\right)$

. 18 ro

. 11 8vo

Parliamentary Debates in (1781 to 1791)

Parliamentary Gazetteer of

Public Records of (Parliamentary)

- $38 \mathrm{vo}$

- 3 fol

. 18 vo

- 1 fol

Tracts on, by Devereux, Tucker, and others

Western Harbours of (Parliamentary Reports,

1641-1690 (Camden Society,

. 14 to

see also Parliamentary Reports.

Irenæus : see St. Irenæus.

Irish Holy Bible

. . . . 1 8vo

Irish Melodies, Music by Stevenson, etc.; Words by Moore 14 to

Irish New Testament. . . . . . . . 1 8vo

Iron Work, Bridges, etc., by Dowling (Weale's Series, ) . . . 1 duo 1862 Mettallum Martis, by Dud Dudley . . . . 1 4to 1665

- its History, etc., by Fairbairn . $\quad . \quad$. . . . . 1 '8vo 1865

- Cast, etc., Strength of, by Tredgold and Hodgkinson - 1 8ro 1861

- Rails, Examination of Barlow's Reports on, by Lecount 1.8 ro 1836

- Manufacture of Great Britain, by Truran . . . . 1 4to 1865

- see also Metals.

Irving (E.), Works (Theological) _ . . . . . . . 5 8vo 1865

- Life of, by Mrs. Oliphant $\quad . \quad$. $\quad . \quad 2 \quad 28$ vo 1862

(Washington), Life of, by his Nephew . . . . 4 8ro 1864

Life and Works . . . . 14 8vo 1859

Vol. 1, Salmagundi; Knickerbocker's History of New York. 2, Sketch Book; Life of Goldsmith. 3, Bracebridge Hall ; Abbotsford; Newstead. 4, The Alhambra; Tales of a Traveller. 5, Conquest of Granada and Spain. 6-7, Life of Columbus, etc. 8, Astoria; Tour on the Prairies. 9, Mahomet and his Successors. 10, Captain Bonneville; Conquest of Florida. 11-14, Life of Washington.

Isaacs (H.), Customs and Traditions of the Jews . . . 18 vo

Isaiah, Notes on the Book of, by Calvin . . . . 4 8ro

Prophecies of, Notes on, by Delitzsch . . . 2 . 2 8vo 1867

Notes on, Ecclesiastes, etc., by Hengstenberg . . . 1 8vo 1860

- Exposition of the 53rd chapter of, by Margoliouth . 1 8vo 1846

Isherrood (B. F.), Steam Engineering (Philadelphia.) . . . 2 4to 1865

Isle of Man, Beauties of England, vol. 3 . . . . . $\quad . \quad 18$ vo 1802

- Its History, etc., by Cumming . . . . . . 1 8vo 1848

___ Monumental Remains of, by Cumming . . . 14 to 1857

Ancient Laws of. Edited by Mills . . . . 1 8vo 1821

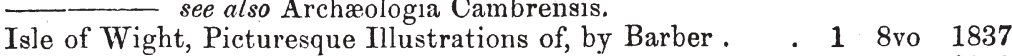

see also Mudie's Hampshire, vol. 3. $\quad . \quad$. 1 8vo 1838

Beauties of England, vol. 6 . . . . . 1 8vo 1805

Handbook for, Surrey, Hants, etc. (Murray) . 1 8vo 1865

History of the, by Worsley. . . . 1 4to 1781

Figure I Birmingham Free Libraries, Catalogue of the reference department (I869) I90. Note the absence of any location mark, and columnar arrangement of number of volumes, size and date 
It should certainly not be used when two different authors have the same name.

Sometimes criticism was made of the use of headings like Fiction, Poetry, Literature, Essays, and suchlike, which were more in the nature of form headings. ${ }^{52}$ Throughout this period there was an ongoing debate among public librarians as to the extent to which the public ought to be reading fiction..$^{53}$ John Frowde of Bermondsey claimed that he had saved money on printing by omitting title entries for fiction. This had the added advantage that it reduced the 'excessive reading of fiction', and no one seemed to have been inconvenienced - 'at any rate no one had complained'. ${ }^{54}$ At Tynemouth in 1904 it was stated that experience had shown that readers usually asked for fiction by author rather than title, and so title entries for fiction had been omitted. ${ }^{55}$

It was, however, quite common to have a separate sequence in the catalogue for fiction (see the references at the foot of Figure 2). This served the purpose of allowing readers to find fiction without having to read through the whole catalogue. Some libraries tried to do the same for Drama, Poetry and even Biography, so that, for example, under 'Biography' in the library of St George Hanover Square in I894 we can find a complete list of all the individual biographies and autobiographies in the library. ${ }^{56}$ Assembling such lists must have demanded great application.

For biography it was certainly essential to provide an entry under the subject as well as the author. Jast recommended doing this in small capitals preceding the author's name. ${ }^{57}$ The subject's dates of birth and death should always be added, as should a brief description of the person's occupation or position. If the title of the book was simply the name of the subject it could then be omitted entirely. All this was designed to ensure brevity, while providing a reasonable amount of useful information about the person and the book.

Even the question of alphabetical order was something that had to be thought out, perhaps for the first time. Steele quotes different textbooks recommending the two main methods (which we would now call word-by-word and letter-by-letter) and advocates the former, as well as giving miscellaneous other advice. ${ }^{58}$ The subject was taken up in more detail by Arthur J. Hawkes, of the National Library of Wales. ${ }^{59}$ His suggestions included some which would be regarded as old-fashioned now, such as filing 'Mr.', 'Mrs.', 'Rev.', etc., as if spelt in full, and even proposing that names differing only by the presence of a single or double L (e.g. Philips/Phillips) should be filed together. I have not found any examples of the latter in practice, and it would be difficult to justify restricting it to variations on the letter L. In 1936 the question was referred to again by Cranshaw, who advocated letter-by-letter arrangement. ${ }^{60}$

Turning to the transcription of the title, we find recommendations which would surprise a modern cataloguer. ${ }^{61}$ We have already seen the inversion of parts of titles to bring a leading word to the front. It was also perfectly acceptable to abridge long titles, and in subtitles even more could (and should) be omitted; Jast gives examples of this, including:

: (being the) Report of the Education Section

for (the Use of) Craftsmen

: Lectures (given) in Oxford (in) ' $83-85$

: (a Treatise on the) Meanings of Armorial Bearings

and many more, where the bracketed words should be omitted. All this would save space, and therefore be more economical. Jast also recommended capital letters for all the principal words, in defiance of Cutter's rules. 
It was quite common to list the titles of individual volumes of periodicals issued by learned societies, though this was not done consistently. George Shaw suggested that the custom was 'more rigid than the cataloguing rules justify'. ${ }^{62}$ Nevertheless he felt that it ought to be extended to include contents of volumes where the papers were by different authors, and indeed this was occasionally done. In the case of multi-volume works it was necessary to show the titles of the individual volumes because otherwise readers would be unable to order them. If an indicator was in use, the accession number of each volume had to be shown even if it had no distinctive title, with the result that even the individual volumes of encyclopaedias might be listed.

For subject headings it was simple enough to take words out of the title and use them, as long as one did not think too much about it. It appears that very few librarians considered the difficulty of synonyms, the assumption being that, if he was going to compile a dictionary catalogue at all, the librarian would have no difficulty in choosing appropriate subject headings. Cutter dealt with the problem quite fully, but either his rules did not find widespread use in Britain or what he said seemed so self-evident as to require no comment. ${ }^{63}$ Quinn mentions that many of the old catalogues made no attempt to standardize subject headings. ${ }^{64}$ Another person who was aware of the problem was Ogle, who gives some examples:

The kind of question which confronts one in revising catalogue copy is this:- Here are four books under Moral Science and six under Ethics - good subject titles each of them, and chosen after examination of the books when the slips were written - are they all to go under Ethics, or under Moral Science? One might be disposed to say, because the names are parallel it does not matter. My judgment would select Moral Science for a popular library catalogue; Ethics for that of a library for educated gentlemen. ${ }^{65}$

It is astonishing that this seems to be practically the only article to consider this matter. Unfortunately, one of Ogle's own catalogues laid him open to ridicule at the hands of Brown and Jast and makes us wonder how seriously he took his own precepts. They say:

It is a wild and weird production. Among the subjects collected together under the remarkably unprocrustean heading, 'Unclassified Items,' is 'Boys.' In the decimal classification we believe that Boys go in class Useful Arts, division Agriculture, section Domestic Animals. ${ }^{66}$

It was inevitable too that titles would simply be misinterpreted, with the result that books were entered under inappropriate headings, and Brown draws attention to a number of these. ${ }^{67}$ On the other hand, an interesting example of an awareness that a word might be used in different senses is shown in Figure 2, where we can see several cross-references from 'Life' to other terms. This still leaves entries where 'Life' is the first word of the title.

Moving on to the question of detail in the description, we find some variation. A constraining factor was usually the desire to limit the entry for each work, if possible, to one line. This is very evident in Figure I, and yet despite this it was here felt necessary to show the number of volumes and the size, features which were elsewhere usually omitted. Even the series is included, but this is understandable as it would often provide useful information. However, it must have been very trying for the compositors having to set the series statement in smaller type on two lines inside full-size parentheses. (It is 
Lichens. Holmes, E. M. and Gray, P. British fungi, lichens, and mosses.

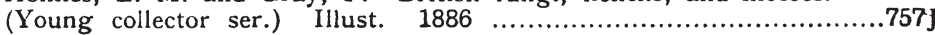

Lichfield Cathedral; by A. B. Clifton. (Bell's cath. ser.) Illust. $1898 \ldots \ldots . .1685 \mathrm{C}$

Liddell and Scott. Greek-English lexicon. [Abridged]. $1887 \ldots \ldots \ldots \ldots \ldots . . . .878 \mathrm{H}$

Liddon, Henry Parry. Analysis of St. Paul's epistle to the Romans. 1893 ...575A

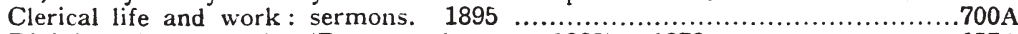

Divinity of our Lord. (Bampton lecture : 1866). 1878 ....................453A

Essays and addresses : Buddhism, St. Paul, Dante. 1892 ......................451A

Life of Edward Bouverie Pusey. 3 vols. Illust. $1893-6$............838 and $867 \mathrm{~B}$

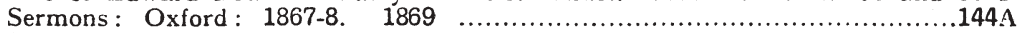

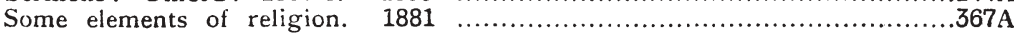

Examination of Canon Liddon's Bampton lectures; by "A clergyman of the Church of England." 1871 ...................................

Johnston, J. O. Life and letters of Henry Parry Liddon. 1904 .............1679B

Lidgey, Charles A. Wagner. (Master musicians). Illust. $1899 \quad \ldots . . . \ldots \ldots . . .1329 \mathrm{~B}$

Liebig, Justus von. Shenstone, W. A. Justus von Liebig : his life and work :

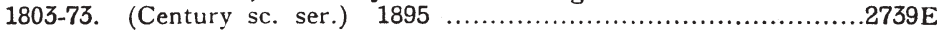

Life, Conduct of. See Christian life ; Conduct of life; Ethics; Future life ; Philosophy.

Life, Duration of. See Vital statistics.

Life, Intellectual. See Intellectual life.

Life, Science of. See Biology.

Life, Social. See Social evolution; Socialism.

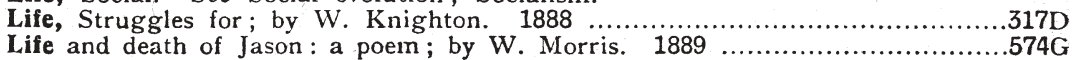

Life and labour: characteristics of men of industry, culture, and genius; by S. Smiles. 1887

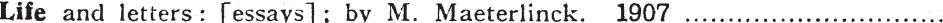

Life and matter : a criticism of Professor Haeckel's "Riddle of the universe."

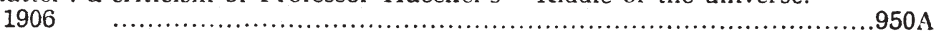

Life in a debtor's prison; by the author of "Five years' penal servitude." $1880 \ldots 584 \mathrm{D}$

Life of lives: further studies in the life of Christ; by F. W. Farrar. $1900 \ldots \ldots .531 \mathrm{~A}$

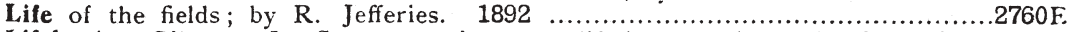

Lifeboats. Gilmore, J. Storm warriors; or, life-boat work on the Goodwin

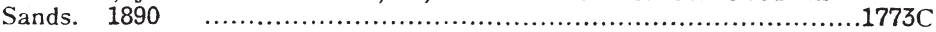

Lifesaving. Roper, R. Saving life at sea. (In "Fisheries Exhibition litera-

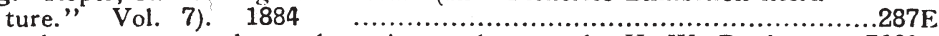

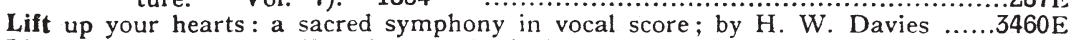

Light. Basset, A. B. Treatise on physical optics. (Mathematical theory of light). 1892

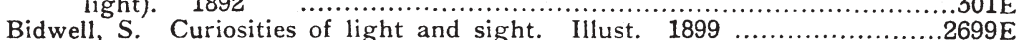

Glazebrook, R. T. Light: elementary text-book, theoretical and prac-

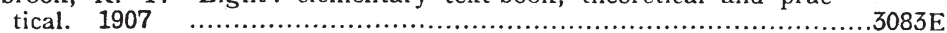

Herschel, Sir J. F. W. On light. (In his "Familiar lectures.") 1868 ......140F,

Mayer, A. M. and Barnard, C. Light : experiments in the phenomena of

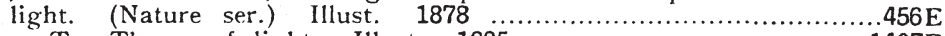

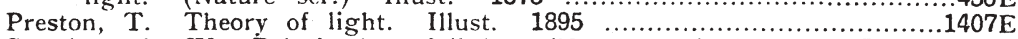

Spottiswoode, W. Polarisation of light. (Nature ser.) Illust. $1876 \ldots \ldots . . .457 \mathrm{E}$

Stewart, R. W. A text-book of light. (Tutorial physics ser.) Illust. $19002769 \mathrm{E}$

Tyndall, J. Notes on light: Royal Institution: 1869. 1879 ..................580E

Vogel, H. The chemistry of light and photography in their application to art, science, and industry. (Int. sc. ser.) Illust. $1888 \ldots \ldots \ldots \ldots .1131 \mathrm{E}$

See also Colour; Electric light; Eye; Magic-lantern; Optics; Physics; Sight; Sun; Telescope; X-Rays.

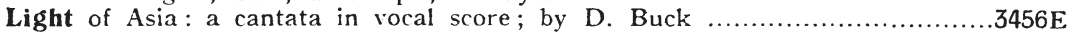
Light of Asia; or, the great renunciation: a poem ; by Sir E. Arnold. $1890 \ldots \ldots . .36 \mathrm{G}$

Light of the world : an oratorio in vocal score; by Sir A. S. Sullivan ...............2170E

Light of the world; or, the great consummation; by Sir E. Arnold. $1891 \ldots \ldots .327 \mathrm{~F}_{\mathrm{T}}$

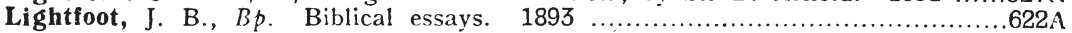

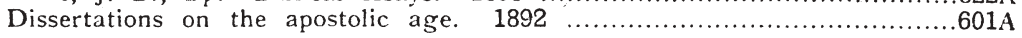

For Novels and Juvenile Literature, see " Fiction" and "Juvenile." 383

Figure 2 Borough of Richmond (Surrey) Public Library, Catalogue of the books in the lending department, 5 th edn (I909) 383. Notice plentiful cross-references, and running footer referring to fiction and juvenile entries (Author's collection) 
not clear how books were requested, for there is no sign of any individual accession numbers or other locating devices, and this catalogue is not alone in this.) Elsewhere and later, the columnar arrangement was abandoned with the exception of the accession number and class letter (e.g. Figure 2).

As for the imprint, it is extremely rare to find anything more than the date of publication. The catalogue of Manchester Free Library of I864 is unusual in including the abbreviated place of publication (e.g. 'Lond.'), but more than this is hard to find anywhere. ${ }^{68}$ The vast majority of catalogues gave the year only, and in cases where there was no date the abbreviation 'n.d.' was used. Ogle states that readers often confuse the date of publication for the library number, and that this could normally be avoided by abbreviating the year to an apostrophe and the last two figures. ${ }^{69}$

The catalogues of Glasgow's branch libraries were widely praised in reviews for their simplicity and clear layout (see Figure 3$).{ }^{70}$ Subject headings are in bold, author entries in capitals and small capitals, and titles in ordinary roman. A short dash is used for repeated works under the same heading, and the rows of spaced out hyphens, rather than leaders, help to produce an uncluttered feel to the page. In this case missing dates are simply omitted. Here too we see some elements of what we should now call the physical description: ports, ill., mus., etc. Physical description had been very detailed at Manchester in I864 but elsewhere this kind of information is rare and inconsistent.

In the Glasgow catalogues occasional additions in square brackets are made, in order to clarify the nature of the work, and even more occasionally a note may explain an obscure title. This was part of a practice known as 'annotation', which came to assume considerable importance in cataloguing. Edward Green of Halifax stated that one of the failings of ordinary dictionary catalogues was this lack of 'explanatory matter' ${ }^{71}$ Space does not permit lengthy discussion of this lost art, but it should be noted that some libraries excelled at it, and books were written wholly devoted to it. ${ }^{72}$ It came to be expected that obscure titles would be explained, and that the period covered by historical works would be mentioned..$^{73}$

In authorities that produced a union catalogue for various branches there was a further occupier of space, because it was necessary to include codes to show the branches at which each book was held.

\section{Arrangement of the classified catalogue}

An early paper discussing how to compile class-lists was written by Brown and Jast in $1897 .^{74}$ They say that it is absolutely essential that 'one of the properly worked out schemes of classification' be adopted, and that the old system of broad classes is quite unsuitable. The scheme is used as the basis of the arrangement, with liberal use of subject headings against each of its divisions. Entry is then by author, except for biographies. The subject index should be as complete as possible, though it is not entirely clear what form it is recommended to take.

Quite an early instance of a classified catalogue is the Newcastle-upon-Tyne Public Libraries catalogue of books in the useful arts, issued in 1903 and arranged by Dewey. ${ }^{75}$ This was described as being a very good example, though the detail of the physical description was questioned. ${ }^{76}$ Based on Dewey, it introduced alphabetic extensions to the numbers, to provide more detailed subdivision than Dewey allowed. 
Glasgow. Murphy (W. S.) History of Glasgow municipal enter-

prise. In his Captains of industry. 1901. ill. - - 92305

- Sherry (C.) The Glasgow Botanic Gardens. ill. _ - _ $\quad-58003$

- Wallace (A.) History of Glasgow. $1882 . \quad$ - $\quad$ - $\quad$ - $\quad 92303$

Glasgow Cathedral. History of the Cathedral and See of Glasgow. 92319 Glasgow University. Book of the jubilee, 1451-1901. 1901. - 37801 Glasgow, a poem ; by J. Mayne. 1803. - - - - - $802 \mathrm{M}$

Glass. For list of other industries, see Industries.

- Powell (H. J.) Principles of glass-making. 1883. bibl. ill. - 66602 Harris."

"With crown and sheet glass; by H. Chance. Plate glass ; by H. G.

- Shenstone (W. A.) The methods of glass-blowing. 1902. ill. 66601 Glass-painting. See Painting.

GLazebrook (RICHD. T.) Laws and properties of matter. 1893. 53011

- Light, an elementary text-book. 1897. ill. - - - - 53507

- Physical optics. 1898. ill. - $\quad$ - $\quad$ - $\quad$ - $\quad$ - $\quad$ - $\quad$ - 53501

- and Shaw (William N.) Practical physics. 1900. ill. - 53006

Gleaming dawn; by J. Baker. - - _ - _ _ _ - 4 B3

Gleichen (Albert E. W., Count) With the mission to Menelik,

1897. 1898. ill. maps. - - - - - - 95802

GLeig (R.) Story of the battle of Waterloo. 1898. - _ _ $\quad 93123$

Glenny (George M. F.) Kitchen gardening made easy. 1895. ill. 63501

Glimpse of the world ; by E. M. Sewell. - - - - - - 46S11

Glimpses of three nations; by G. W. Steevens. 1901. - - 91011 London. Paris. Germany.

Gloag (Paton J.) Exegetical studies. 1884. - - - - 22022

- The life of Paul. map. - - - - - - $\quad$ - $\quad$ - $\quad$ - 22508

Gloucester. Spence (H. D. M.) Gloucester Cathedral. In Our English minsters, v. 1. ill. - - - - $\quad-91619$

Glowworm ; by M. Bateman. - - - _ _ _ - $\quad$ - 26 B1

GNeist (RUdolf v.) English parliament, 800-1887. 1895. port. 32803

Goadby (EDwin) The England of Shakespeare. ill. - $\quad-91608$

Cod. See Miracles. Theology.

God and the ant, [a novel]; by C. Kernahan. - - - $\quad 24404$

God seeker [a novel] ; by P. Rosegger. - - - - - 56R1

Goder (Fred.) Lectures in defence of the Christian faith. - 23905

Godfrey (Elizabeth) A stolen idea. - - - - - 29G1

GodkIN (G. S.) Life of Victor Emmanuel II. 1880. - - - - V041

God's fool, a story ; by M. Maartens. - - _ _ _ 2 M2

God's rebel; by H. Fuller. - - - _ - - - - 59F1

Godwin, Mary W., [a biography]; by E. R. Pennell. 1893. - G201

Godwin, William. Stephen (Sir L.) William Godwin's novels. In his Studies of a biographer, v. 3. 1902. - - - E8S3

Goebel (Sikgfried) The parables of Jesus. 1900. - - - $\quad-22621$

Goethe (Johann W. v.) Autobiography. Annals. 2 v. port. G171-2

- Correspondence between Schiller and Goethe, 1794-1805; trans. with notes by L. D. Schmitz. 1877-98. 2 v. - - 
NATURAL HISTORY, PHILOSOPHY, ETC.

\section{RADIUM.}

903 Interpretation of Radium (1909)

F. Soddy

230 Religion and Science, History of the Conflict between (1878).

J. W. Draper

49 Rents and Purchases, or the Valuation of Landed Property-Woods, Minerals Buildings, \&c (1879)...............J. Scott

566 Revolution, A Century of (1890).

W. S. I illy

84 Rhetoric (1849)..............Dr. R. Whately

384 Rochdale Literary and Scientific Society Transactions (1878-88)

Sanitation. Seo also Hygiene.

313 Sanitary Work in Smaller Towns and in Villages (1884)...................... Slagg

1192 Sanitation and Plumbing, Principles of (1924) ................................. H. Bew

1023-28 Schoot. Handwork, The Book of, Edited by $\mathrm{H}$. Holman 1023 Sandwork, Toymaking, Brushwork, Carpentry, Domestic Handicrafts, \&c.

1024 Weaving, Pencil, Pastel and Colour Drawing, Metal Work \&c.

1025 Paper and Clay Modelling, Chip Carving, Repousse Work, \&c.

1026 Colour Work, String Work, Wood and Metal Work, \&c...

1027 Leather Work, Wood Carving, Free Arm Drawing, Coiled Basketry, \&c...

1028 Chalk Carving, Cabinet Work, Needlework, Basketry, Gardening, \&c

SCIENCE (General).

598 Rough Ways Made Smooth, Familiar Essays on Scientific Subjects (1893) .... R. A. Proctor 315 Science and Culture (1881)

331-5 Science Lectures delivered in Manchester (1871-81)

331 Ohemistry, Zoologty, Physiology.-332 Astronomy, Physiography, Sanitary Science, etc.-333 Ethnology, Natural History, Physics, etc. -334 Arctic Discoveries, Geolology, Palaentology, etc. - 335

Biology, Botany, Ethnology, etc.

391-400 Science Primers:-

391 Introductry (1880)

392 Chemistry (1884)

Prof. Huxley.

393 Physics (1884) H. E. Roscos
394 Physical - Geography (1879)

A. Geikie

395 Geology .............. A. Geikie

396 Physiology (1883) .. M. Foster

397 Astronomy (1884)

398 Botany (1881)

J. N. Lockyer

Sir J. D. Hooker

399 Logic (1883) ... W. S. Jevons

400 Political Economy (1884)

W. S. Jevons

1056 Science, The Realities of Modern

(1919) .................... J. Mills

1168 Science and the Infinite (1921)

S. T. Klein

SCOUTING. (Boy Scouts).

981 Boy Seout's Companion (1912).

982 Camping and Pioneering (1915) ...............

983 Scout Handicrafts

984 What a Scout should Know....M. Adams

1195 The Complete Scout............... Adams

576 Screws and Screw Making

238 Senses-Five Senses of Man (1876)........ Prof. Bernstein

1172 Servantless House, The (1920).....

R. R. Phillips

SHORTHAND.

50 Pitman's Shorthand Instructor (1913).... I. Pitman

1031 Sign of Four in Pitman's Shorthand.... A. C. Doyle

1105 Slide Rule, The (1904)...C. N. Pickworth 817 Slide Rule, The, and How to Use it (1901) ................................ C. Hoare 668 Soap Bubbles and the Forces which Mould them (1890)................. V. . Boys

506 Social Equality...........W. H. Mallock 222 Sociology, Study of (1877)....H. Spencer 693 Some Hobby Horses, or How to Collect Stamps, Coins, Seals, Crests, and Scraps (1895) ........... C. A. Montressor

239 Sound, Theory of, in its Relation to Music ..................... Prof. P. Blaserna 240 Spectrum Analysis, Studies in

J. N. Lockyer

SPEECH. (See also Voice).

1123 Extempore Speaking, The Art of (1921)

H. Ford

940 Human Speech (1908)

M. C. Macnamara

1035 Public Speaking and Debate (1918)........

G. J. Holyoake

1171 Speeches ?and Toasts and Chairman's Guide ......................................

Figure 4 Clitheroe Free Library, Catalogue of the books in the lending and reference departments (I925) I20, showing part of Class G. A late example of a catalogue arranged by main classes, within which arrangement is alphabetical by subject or title (Author's collection) 
The old 'main classes' system of classification lingered on too, and Figure 4 shows a late example of a classified catalogue on this arrangement. Class G covers a very wide spectrum of subjects, and the subdivision within it is simply alphabetical. A confusing feature is that although there are many sub-headings in capitals, not all subjects are distinguished in this way. It is therefore essential to notice, from the presence of a rule, where each sub-heading ends, because it may well be followed by several individual entries without sub-headings. This is very obvious in the entries following SHORTHAND: although it might be thought that the next heading was SPEECH there are in fact several intervening titles. There is an index of authors, which is somewhat inconsistent as to whether the heading is repeated for different works by the same author.

Contemporary with Clitheroe, Figures 5 and 6 provide contrasting examples of the arrangement of catalogues using classification schemes. Each uses Dewey, but Gloucester gives prominence to words for the subjects, showing the numbers (very repetitively) only at the ends of the entries, whereas Bolton more logically uses the Dewey numbers accompanied by words as headings, thus obviating the need to show the numbers every time. (Interestingly and unusually, Gloucester sometimes shows the number of illustrations.) Each of these catalogues has an author index, in each case giving brief details of the title, along with the class-number. Each also has a subject index, and these differ considerably. Gloucester's has two kinds of entry: some are simply subject headings, leading to a Dewey number. Others are more specific, and refer to specific works, giving the author and class-number as well. In fact, although entitled 'Subject index', it is a combined subject-title index, and is rather like a dictionary catalogue but without the authors.

\section{Reviews of printed catalogues}

One of the interesting aspects of the printed catalogue which is absent from any subsequent kind is that it can be reviewed as a book in the professional press. The period of the printed catalogue was also a time of very forthright reviews, which means that we can find some trenchant comments. One catalogue (of an unnamed library), for example, was described as being 'in many respects a complete text-book to the shortcomings of the dictionary form'. ${ }^{77}$ It was crowded with misprints and had many blind cross-references. 'Whenever the compiler has been in doubt about a book he has not troubled to assign it to any subject-heading.' There was also great confusion between general and specific headings, and in short 'it would be impossible to do justice to the humours, eccentricities, woeful mistakes and ignorant flounderings of this catalogue'. The reviewer ends by suggesting that it is perhaps impossible to compile a satisfactory dictionary catalogue.

A catalogue of Hackney Reference Library in I90I, despite criticism for serious errors in forms of name, is in other respects described as a good catalogue. ${ }^{78}$ A Bournemouth catalogue of 1902 receives criticism because of the inconsistent entries under its subject headings, but still earns praise for the amount of detail included in the descriptions. This is in contrast to a supplementary catalogue from South Shields, where details of illustrations and other physical aspects were missing, 'which, in reference library catalogues especially, are inexcusable omissions'. Some series are entered under issuing society only, 


\section{SCIENCE, $595 \cdot 7-598.2$}

*Gordon (W. J.) Our country's butterflies and moths and how to know them. (1,00o examples in colour). 2 copies.

Kirby (W., and W. Spence). Entomology. I873... ...

Maeterlinck (M.) Life of the bee. Trans. by.Sutro. Igor.

*Miall (L. C.) Natural history of aquatic insects. I903. ...

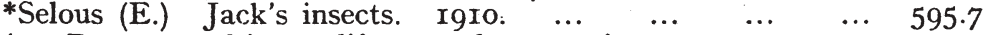

* - Romance of insect life. I906. 2 copies... $\quad \ldots \quad$... 595.7

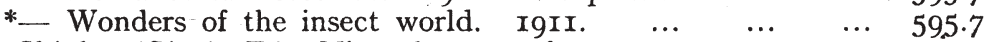

Shipley (Sir A. E.) Minor horrors of war. I9I5. ... $\quad . .54595 .7$

South (R.) Butterflies of the British Isles. (col. illus.) I906. 595.7

- Moths of the British Isles. (col. illus.) 1907-9. 2 series. 595.7

*Staveley (E. F.) British insects. (col. hl.) [I87I]. .. 595.7

Step (E.) Insect artizans and their work. (illus.) [I9I9]. 595.7

Ward (J. J.) Insect biographies with pen and camera. $\begin{array}{lllllllll}\text { (illus.) } & \ldots & \ldots & \ldots & \ldots & \ldots & \ldots & \ldots & 595.7\end{array}$

*Westell (W. P.) Story of insect life. $\quad$ I907. ... $\quad \ldots \quad \ldots \quad \ldots \quad 595.7$

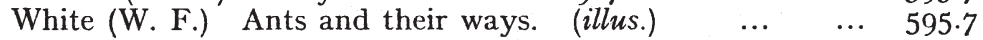

\section{FISHES. THE FROG. REPTILES.}

Aflalo (F. G.) British salt-water fishes. (col. plates). I904. $\quad .597$

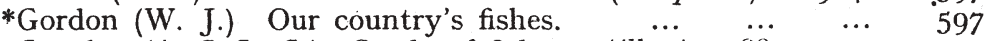

Günther (A. C. L. G.) Study of fishes. (illus.) I880. $\quad . . .597$

Holder (C. F.) Game fishes of the world. (illus.) $\ldots . \quad \ldots \quad 597$

Maxwell (Sir H.) British fresh-water fishes. (illus.) I904. 597

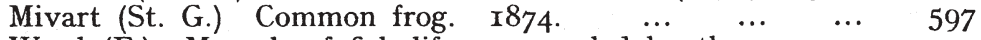

Ward (F.) Marvels of fish life as revealed by the camera.

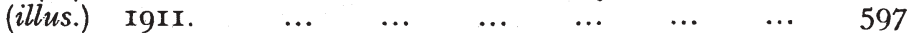

Boulenger (G. A.) Snakes of Europe. (illus.) I9I3 $\quad \ldots \quad$ 598.I

Cooke (M. C.) Our reptiles: lizards, snakes, newts, toads,

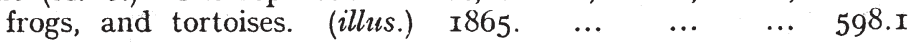

\section{BIRDS}

Beebe (C. W.) The bird: its form and functions. I907. ... 598.2 Bond (J. A. W.) Bird life in wild Wales. (illus.) I903. ... 598.2 Carrington (E.) The farmer and the birds. I898. ... $\quad \ldots \quad 598.2$ Collett (A.) Handbook of British inland birds. Igo6. (illus.) 598.2 Dixon (C.) Lost and vanishing birds. (illus.) $1898 . \quad \ldots .598 .2$

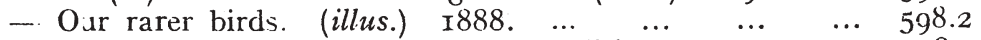
Finn (F.) Ornithological and other oddities. I907. $\quad \ldots \quad 598.2$

*Gordon (W. J.) Our country's birds and how to know them. $\begin{array}{llllllll}(\text { col. } p l .) & \ldots & \ldots & \ldots & \ldots & \ldots & \ldots & \ldots\end{array}$

- Eggs of the native birds of Britain and list of British birds; $\begin{array}{lllllll}\text { past and present. } \quad(200 \mathrm{col} \text {. fig.) } & \ldots & \ldots & \ldots & \ldots & 598.2\end{array}$

Halliday (W.) Book of migratory birds. [I9Io]. ... $\quad \ldots \quad 598.2$ Heatherley (F.) The peregrine falcon at the eyrie. I9I3... 598.2

Horsfield (H. K.) English bird life. I908. ... $\quad \ldots \quad \ldots \quad \ldots \quad 598.2$

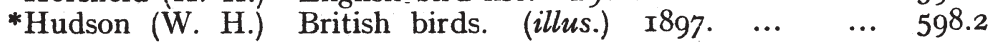
84

Figure 5 Gloucester Public Library, Catalogue of the lending department, new edn (1924) 84. An example of a classified catalogue, arranged by Dewey but using subject headings for main divisions 


\section{PHYSIOLOGICAL AND STRUCTURAL BOTANY-Continued}

\subsection{Plant Geography}

Bower (F. O.) The origin of a land flora: a theory based upon the facts of alternation. Illus. 1908.

- Another copy......R.

Dodoens (Rembert) A nieuue herball; or, Historie of plantes; translated out of French by Henry Lyte. Illus. 1578......R.

Grisebach (A. H. R.) Report on the contributions to botanical geography during the years 1842 to 1845 , translated by W. B. Macdonald. Ray Society, 6, 16. 1846-9......R.

Hardy (M. E.) The geography of plants. Illus. 1920.

An introduction to plant geography. Oxford Geographies. Illus. 1913.

Meyen (F. J. F.) Outlines of the geography of plants; translated by Margaret Johnson. Ray Soriety, 7. 1846......R.

Schimper (A.F.W.) Plant geography upon a physiological basis; the authorized English translation by W. R. Fisher; revised and edited by Percy Groom and I. B. Balfour. Portrait: Illus. 1903......R.

Wallace (A. R.) Island life; or, The phenomena and causes of insular faunas and floras; including a revision and attempted solution of the problem of geological climates. Maps. Illus. 1880.

\subsection{England}

Adams (H. I.) Wild flowers of the British Isles: revised by J. E. Bagnall. 2 vols. Illus. $1907-10 \ldots . . . R$.

Babington (C. C.) Manual of British botany: containing the flowering plants and ferns arranged according to the natural orders; edited by Henry and James Groves. 9th edition. 1904.

Baxter (William) British phænogamous botany; or [Coloured] Figures and descriptions of the genera of British flowering plants. 6 vols. $1834-43 \ldots$. . .

Vol. 1. 2nd edition.

Bentham (George) Handbook of the British flora: a description of the flowering plants and ferns indigenous to, or naturalized in, the British Isles. 5th edition. 1887.

- Another edition. 2 vols. Illus. $1865 \ldots$.... R. Kewensibus servata definita. 3 vols. $1862-83$.....R.

Contents:-Vol. I.Part 1. Sistens dicotyledonum polypetalarum ordines 56 . [RanunculaceasConnaraceas]. 1862. Part 2. Sistens dicotyledonum polypetalarum [LeguminosasMyrtaceas]. 1865. Part 3. Sistens dicotyledonum polypetalarum ordines 83. [Ranunculaceas-Cornaceas]. 1867. Vol. 2. Part I Sistens dicotyledonum-gamopetalarum ordines 6. [Caprifoliaceas-compositas|. 1873. Part 2. Sistens dicotyledonumgamopetalarum ordines 39. [Stylidieas-plantagineas]. 1876. Vol. 3. Part 1. Sistens dicotyledonum monochlamy-dearum ordines 36. [Nyctagineas-ceratophylleas] et Gymnospermearum ordines III. [Gretaceas-cycadaceas]. 1880. Part 2. Sistens dicotyledonum monochlamydearum ordines 34. [Hydrocharideas-Gramineas].

Blackwell (Elizabeth) A curious herball containing five hundred cuts of the most useful plants which are now used in the practice of physick: engraved on folio copper plates [and hand painted] after drawings taken from the life; to which is added a short description of ye plants and their common uses in physick. 2 vols. 1739 ......R.

Catlow (Agnes) Popular field botany: containing a familiar and technical description of the plants most common to the various localities of the British Isles, adapted to the study of either the artificial or natural systems. 2nd edition. Illus. 1849.

Crawford (J. H.) The wild flowers. 2nd edition. Illus. 1909.

Curtis (William) Flora Londinensis: containing a history of the plants indigenous to Great Britain; illustrated by [coloured] figures of the natural size; a new edition, enlarged by George Graves. 5 vols. 1817-28.....R.

Vols. 4 and 5 , the descriptions by Sir Wm. Jackson Hooker.

Daglish (E. F.) Our wild flowers, and how to know them. Illus. 1923.

Deakin (Richard) Florigraphica Britannica; or, Engravings and descriptions of the flowering plants and ferns of Britain. 4 vols. $1848-57 \ldots \ldots$.

Figure 6 Bolton Public Libraries, Catalogue of books in the central lending and reference libraries. Natural science, 2nd edn (I927) 98. An example of a classified catalogue, arranged by Dewey and using Dewey numbers with words for the main divisions (Author's collection) 
so that if someone is looking for the Letters of Robert Grosseteste and 'is unaware that they were published by the Record Office, the chances are a hundred to one he will "just have to want"' ${ }^{79}$

Annotation could be a major pitfall; as it was by its nature very subjective it was almost inevitable that the reviewer would disagree with the compiler. Its absence was deplored in a catalogue issued in 1902 by the Metropolitan Borough of Stepney, and there were many other shortcomings too. ${ }^{80} \mathrm{~A}$ branch catalogue from Bootle is criticized on various counts, not least that it was almost impossible to find any of the advertised annotations at all: 'after a diligent search we found one attached to Stevenson's "New Arabian Nights." It is particularly illuminative too: "contains several short stories." On the other hand, the review of the new Hampstead catalogue after a critical start ends in praise: 'undoubtedly the best general catalogue published in England for several years past. ${ }^{82}$ Some librarians must have come to dread reviews of their own catalogues. One reviewer even recommends the adoption of the card catalogue, not only because it is always up to date, but because it 'need never be reviewed'. ${ }^{83}$

\section{Costs}

The two great disadvantages of the printed catalogue were the expense of producing it, and the fact that it was inevitably out of date before it even appeared. Libraries adopted different methods of coping with this. Aberdeen Public Library issued a complete catalogue when it opened in I884 with I4,525 volumes, and sold it 'at a moderate price'. Supplementary lists of additions were then issued, until by I897 it was time to issue a complete new catalogue. ${ }^{84}$ Some saw the cost of the printed catalogue as being out of all proportion to its value to readers. For example, we are told that in 1889 one library issued a catalogue at a cost of $£_{\mathrm{I}} 60$ for 5000 copies. By I 894 it was found that to produce a revised catalogue on similar lines would now cost $£_{\mathrm{I}} 80$ for only 2500 copies, and it was therefore decided to produce four separate class-lists instead. These were produced at a total cost of only $£ 8 \circ .{ }^{85}$ Quinn states in I9OI that a catalogue costing 2s. or 2 s. $6 \mathrm{~d}$. per copy to print had to sell at $6 \mathrm{~d}$. or $9 \mathrm{~d}$. Moreover, once a list of additions had been published, it was inevitable that readers would prefer to buy that at Id. rather than bother with the main catalogue. ${ }^{86}$ In 1908 Brown quotes a very much higher cost for the dictionary catalogue of a large library: ${ }^{87}$

A complete Dictionary Catalogue, edition 5,000 copies

Cost

A " Classified " in five sections

$£_{\mathrm{I}, 050}$

A Select Catalogue of best books only, 5,000 copies

450

A complete Manuscript Catalogue

He was of course trying to prove the futility of the printed dictionary catalogue, but nevertheless the figure quoted for it seems grossly inflated.

At Birmingham it was found that the edition of a catalogue was seldom sold out, and it was therefore decided that catalogues for the branch libraries should be sold at a penny, even though this was a considerable loss. About three times as many were sold, and a new one could be issued every two or three years. ${ }^{88}$ This policy was praised by 
Richard Mould, Librarian of Newington, because cheap catalogues would 'get into the homes of the people, by which I mean the class of people it is our highest duty to reach' ${ }^{89}$

\section{Physical production}

The production of the printed catalogue was a major task and something which occupied much of the librarian's time. In order to prepare copy for the printer it was necessary to have each entry written on a separate slip or card, and it was quite common to send these to the printer in bundles, suitably tied together. ${ }^{90}$ Slips might alternatively be pasted on to larger sheets, but the time taken to do so did not necessarily justify the slight saving in printers' costs. ${ }^{91}$

Savage gives an entertaining account of how some libraries produced their new catalogue, and this is worth quoting at some length:

About fourteen I 'compiled' a catalogue after the librarian had taken an hour to tell me how. Tools: two complete copies of the title-a-liner of some recent branch, probably on Tyneside, whence my first and second chiefs brought their accents and their Bible, The Newcastle Chronicle; catalogue slips, cutting-board, mounting materials, knives, paste. Method: cut the catalogues into entries, including references; paste these fly-away scraps on slips; alphabet the whole by authors so that all entries for each book came together; then write book orders on columned foolscap, and get a signed note from the chief telling the bookseller to supply the cheapest editions in cloth. Books published since the rifled catalogue was printed were chosen and catalogued by the librarian, who passed the slips to me: that was his main share. Nearly all was scissors-and-paste, checking, numbering, alphabeting, a practice usual except under good librarians, of whom there were few. Simple, eh? Theft? - who cared? Stolen cataloguing got worse as the process was repeated, for some of the scraps were bound to be lost. ${ }^{92}$

How typical this was it is impossible to know. Savage was writing sixty years after the event, and from the tone of his book was probably prone to some exaggeration, but nevertheless there must have been occasions when this kind of procedure was adopted. When a single authority was setting up a new branch it would be perfectly excusable to use the same catalogue. One cannot imagine this happening very often, because of the growth of new publications, but there is evidence that it sometimes did: the catalogue of the Elswick branch of Newcastle-upon-Tyne Public Libraries was used as the basis for the new branch at Heaton. ${ }^{93}$ An interesting sidelight is shed by Green in his reminiscences of the I880s at Halifax, where the first printed catalogue contained many books which were not in stock but which they hoped to purchase later. ${ }^{94}$ These books had to be shown as continually on loan, to the puzzlement of borrowers. No doubt, considering the predictable lifespan of a catalogue, his experience was not unique.

Ernest Baker described the cumbersome procedure to be adopted when preparing a revised edition of the printed catalogue. It was necessary to cut up two copies of the existing one and mount all the entries on cards, so that all the new additions could be interfiled. He concludes by saying that the card catalogue 'has so many good points that it is, perhaps, the best form to adopt at the beginning before publishing any catalogue at all'. ${ }^{95}$ At this period (I898) it was clearly still regarded as only a preliminary to the printed catalogue, not as a substitute for it. 


\section{Linotype and Monotype}

When the Linotype machine was introduced it was natural that librarians should consider whether it would save money. On a Linotype, each line of type is cast as a solid 'slug', rather than separate characters, and the assumption was that it would be possible to buy these from the printer for a nominal fee and keep them. It would then be necessary only to have the new entries cast and inserted, and out-of-date entries removed. The proposal seems to have been first made by Thomas Aldred, of St George the Martyr Public Library, London. ${ }^{96}$ This prompted a printer to reply, to the effect that the saving would not be as great as he imagined, partly because much of the preparatory work would be the same but also because he felt it was very unlikely that printers would be willing to set new entries a few at a time. ${ }^{97}$

Nevertheless some libraries clearly went ahead, and it appears that the first public library to have its catalogue printed by Linotype and where the library authority then purchased the type was Lincoln. ${ }^{98}$ Another early user was Barrow-in-Furness, whose catalogue was printed (at Bury) in I899. ${ }^{99}$ Aldred had worked there before going to St George-the-Martyr, and was probably instrumental in its production.

The Monotype machine, which became available slightly later than the Linotype, cast individual 'sorts' of type rather than one-line slugs. The keyboard was also quite separate from the casting machine, unlike the Linotype. Doubleday refers to an 'experiment' being carried out at Hampstead. ${ }^{100}$ The description is unclear, but it appears that he hoped it might be possible for cataloguers to compose their entries directly using the keyboard. He certainly had high expectations of cost-saving, and gives detailed estimates. Unfortunately there is no sequel to these articles, and it is impossible to know of the project's success.

\section{The coming of the card catalogue}

By the I890s the long-term future of the printed catalogue was beginning to be questioned. Jast, for example, wrote: 'The days of exhaustive public library catalogues between single covers are seemingly drawing to a close. ${ }^{101}$ This sentiment was echoed by Thomas E. Maw, Librarian of King's Lynn: 'The ponderous Dictionary Catalogue with its mass of meaningless entries seems to be rapidly sinking into its grave.' ${ }^{102}$ At about the same time Green stated that 'in all progressive libraries, in addition to printed catalogues, a good card catalogue is considered indispensable'. ${ }^{103}$ Library suppliers were beginning to advertise card catalogue equipment, sometimes with strings of recommendations from librarians. ${ }^{104}$ The card catalogue was perhaps first used as a supplement to the printed, as was the case at Cardiff, where the cards were kept on the lending library counter. ${ }^{105}$

In 1907 W. J. Willcock, Librarian of Peterborough, questioned the continuing utility of the large printed catalogue. ${ }^{106}$ Here he discusses the 'battle of the dictionary and classed' catalogues, asserting that the latter is comparatively the cheaper, and therefore the lesser of two evils. He says that at least $75 \%$ of printed catalogues have 'no bibliographical quality', and that a very small percentage of library users actually purchase them. He calls the complete printed catalogue 'a thing of the past' and predicts, correctly 
as it turned out, that the card catalogue 'will be used more extensively in the near future'. A report on the catalogues at Liverpool Public Library in I9Io refers to card and sheaf catalogues only, and it is clear that since the publication of a printed catalogue in I89I there had been no intention to produce more in that form. The only problem was that there had been so much wear and tear on the cards that 16,600 were retyped during the year; this presumably does not represent an annual problem, rather that they all happened to be done during that period. ${ }^{107}$

In view of the interest in the card catalogue it is surprising that it was not until I9II that Sayers and Stewart wrote a series of articles (later published as a book) about it. ${ }^{108}$ Much of this concerns general rules for cataloguing, and has nothing specifically to do with card catalogues as such, but it is a useful guide to what must have still been something of a novelty to many librarians. Reference is made to the printed catalogue cards which were available from certain libraries in the United States, including the Library of Congress. The writers conclude by saying that the card catalogue is 'the catalogue of the future', because any central or co-operative cataloguing demands the card as the unit.

Naturally some librarians adapted the card catalogue in unusual ways, or tried to make it do more than was originally intended. One such was Ernest Crowther, of Colne Public Library, who turned it into a kind of indicator, displaying the cards in racks in such a way that the top edge of each could be read. ${ }^{109}$ When a borrower wanted a particular book, he removed the card from the rack and used it to request the book. This had the effect that the catalogue showed only the material which was actually available for borrowing at the time. The system is described as catering for about 4000 items, and it is hard to see how it could be applied in a larger library. As it is, it is an unusual precursor of the facility, now universal in online catalogues, of being able to find out whether an item is on loan before looking for it. The disadvantage, of course, is that the books which are on loan might as well not exist.

\section{The sheaf catalogue}

The card catalogue was not the only alternative to the printed one; another was the sheaf catalogue, in which each entry was printed or written on an individual slip, and the slips were clasped in small binders. Stewart, of Islington, wrote a series of articles about it, which were subsequently published as a book. ${ }^{110}$ It seems likely that both sheaf and card came into use about the same time, because either would have been a suitable medium for assembling catalogue entries prior to printing. Certainly both appear in Greenwood's library year book of 1897 .

It was difficult for librarians to decide between the card and sheaf catalogues. Jast compared the two, and actually went to the trouble of having part of his reference library catalogued on 'sheafs' and part of the lending on cards. ${ }^{111}$ His conclusion was that the cards were better because they were harder-wearing, more legible and less susceptible to dirt. The assumption that the public preferred sheaf catalogues because they resembled printed catalogues in form was not borne out by his experience. The chief disadvantage of the card catalogue was that it was necessary to buy a card cabinet rather in advance of one's present needs to allow for growth. A final consideration was that the adoption of the sheaf catalogue would cut the library off from the possibility 
of ever using printed cards. (British librarians hoped to follow the example set by the Library of Congress and establish a bureau to issue printed cards.)

Certain other unusual suggestions were made for the physical form of catalogues. One was the 'Rand visible index', where strips of card were displayed in vertical frames on a revolving stand. ${ }^{112}$ The writer, who was apparently using it at Farnworth, prophetically started his paper 'Is the printed catalogue doomed?' It was, of course, but not as a result of this cumbersome device. Nevertheless the idea was revived more than once later: in an unnamed county library in the late I930s and in the University of Malaya in the late I950s. ${ }^{113}$

\section{Advantages and drawbacks of the printed catalogue}

Regardless of whether it was dictionary or classified, the printed catalogue was seen to have some advantages. Guthrie Vine maintained that classification needs to be displayed in a graphic manner, which can only be done in a printed catalogue. ${ }^{114}$ There is much to be said for this view, because it is very difficult to browse in either a card or a sheaf catalogue unless it has plentiful guides, and the facility provided by the printed catalogue has never been repeated.

The chief benefit usually adduced for the printed catalogue was that without it readers living at a distance from the library would have great difficulty finding out what it contained. In the case of people to whom it applied, this was really unanswerable, and it was not until the development of online and web catalogues in recent years that it has again become possible for readers to find out from afar what is in their local library. However, it is pointed out many times that sales of printed catalogues were actually very low, and that therefore the number of possessors of the catalogue was small. ${ }^{115}$

The printed catalogue had an educational function too: those who did purchase it and take it home could browse through it and have their eyes opened to all sorts of subjects apart from what they were looking for. Miss A. S. Cooke, County Librarian of Kent, recalled her enthusiasm for this at the age of fifteen, when she used to use the classified catalogue of Gloucester Public Library. This early experience led her to believe that the printed catalogue was 'a help and an inspiration'. ${ }^{116}$ Finally, the possession of another library's catalogue could also be useful to librarians themselves, because 'to some extent it enabled librarians to make actual use of the resources of other libraries' ${ }^{117}$

The main drawbacks have already been mentioned, namely cost and the difficulty of keeping the catalogue up to date. A less obvious difficulty was that because the printed catalogue was fixed in its form and was consulted for several years there was a tendency to try to replace any books which were lost, simply because they were in the catalogue. We are told of a case (not named) where a library sometimes had to pay three shillings to obtain an out-of-print novel in order to keep the catalogue correct. ${ }^{118}$

\section{The inter-war years}

Following the First World War there was a great increase in production costs, and the decline of the printed catalogue therefore continued more sharply. The abolition of the 
penny rate limit by the Public Libraries Act of I9I9 might in theory have meant that more money was available, but it is probable that many librarians had no great desire to see the printed catalogue continue. ${ }^{119}$ The same Act empowered county councils to run library services if they wished. One might have expected that they would be unlikely to adopt printed catalogues, both because these were already in decline and because it would not be feasible to produce one for a whole county. Some county libraries however did produce them. Captain Richard Wright, County Librarian of Middlesex, stated that 'an elaborate printed catalogue' was essential for rural libraries, and implied that those counties that had not yet produced one would do so. ${ }^{120}$ Another supporter was Miss Cooke, referred to above, the County Librarian of Kent. She took up her post in November I92I, the service started in I922 and a catalogue was issued in I924. ${ }^{121}$ An advocate of the printed catalogue, she says that when a new one was issued in I928 the issue of non-fiction doubled. ${ }^{122}$ This catalogue, which seems to have excluded fiction, was arranged by Dewey and sold at a shilling. ${ }^{123}$

By the late I920s the decline was generally continuing, the increased cost of printing being to blame. ${ }^{124}$ There were, however, a few exceptions: Fife County issued one of 462 pages in dictionary form, because this was felt to present fewest difficulties for users. ${ }^{125}$ The County Librarian, Mrs Alexander Henderson, felt that even the 'best educated type of person' was 'quite at sea' when confronted with a classified catalogue; she had conducted tests which proved this. 'The fact that the people know the alphabet and the opposite fact that they do not know classification should be a fine argument in favour of the dictionary catalogue. ${ }^{126}$ Moreover, she felt that a dictionary catalogue was no more expensive than classified. In I929 Midlothian issued 'the most comprehensive catalogue of general books that has yet been issued by any county library in this country'. ${ }^{127}$ About the same time Hertfordshire issued a classified catalogue, and reported the increase in the issue of non-fiction books as a result. ${ }^{128}$ Glasgow issued a classified catalogue of additions since I9I5, and this occupied about Iooo pages, selling for $2 \mathrm{~s} .6 \mathrm{~d} .{ }^{129} \mathrm{R}$. J. Gordon, City Librarian of Leeds, though saying that open access had practically abolished the printed catalogue, nevertheless felt that many readers would still find it useful. ${ }^{130}$ Rochdale produced a printed classified catalogue of non-fiction stock over a period of years. ${ }^{131}$ Bethnal Green continued to issue an annual catalogue of additions. ${ }^{132}$ Most recognized, however, like Sayers, that 'The only possible current catalogue is one in which the entries are mobile'. ${ }^{133}$ His main difficulty with the card catalogue was its bulk, and for this reason he was inclined to favour the sheaf catalogue but for the fact that it was impossible to put Library of Congress cards into one.

Of the five county librarians contributing to a 'symposium' on the question, only Miss Cooke of Kent was wholly in favour of a printed catalogue, and even here it would be of non-fiction only. The expense of printing it, she says, is justified by the greater use made of the library. The other contributors, including Richard Wright of Middlesex, largely favoured printed selective booklists. ${ }^{134}$ No reference is here made to card catalogues, but we can see from the Libraries, museums and art galleries year book for 1937 that by this time they were in use in almost all counties, and nearly all were classed catalogues. ${ }^{135}$ While some still held the view that county libraries must produce 'some form of printed guide to stock', the assumption was that it would be selective.

At that time county and municipal libraries would have differed much more than they do today, and a second symposium was devoted to the views of four municipal 
librarians. On catalogues, however, their views do not differ significantly from those of their county counterparts. Gordon, of Leeds, now believed that 'the day of the full printed catalogue is past, or very quickly passing, despite the few libraries that still cling to them'. ${ }^{136}$ W. A. Munford, Chief Librarian of Dover, admitted that 'in the days of "Keep out" librarianship' the printed catalogue was essential, and because it was essential it tended to become the only tool available. The only remaining supporter of the printed catalogue appears to be G. F. Vale, Librarian of Bethnal Green, who rejects the 'totally fallacious claim' that a printed catalogue is out of date as soon as it is printed. He offers no evidence for this, however, and it becomes clear that he relies on annual lists of new books acquired during the year, together with a card catalogue. As for the argument about the cost of printed catalogues, he says, 'Why librarians should constantly harp on this it is difficult to imagine', but he has nothing to say to disprove it. ${ }^{137}$ Despite this it is clear that the printed catalogue was regarded as a thing of the past. ${ }^{138}$ The Libraries, museums and art galleries year book for 1937 shows thirty-one libraries as still using printed catalogues only, but none of these are of recent foundation and they are mostly small authorities (some seem to have been omitted in earlier directories). A further nineteen have both printed and another form. These figures are a very small proportion of the total. In the early years of the war this decline was lamented by the Library Review, which painted a rosy picture of a family sitting at home with the catalogue deciding what to borrow. ${ }^{139}$ It was suggested that perhaps afterwards the Library Association might issue a 'standard catalogue', but it is difficult to see how such a thing might work unless all libraries acquired the same stock.

As for the inner form, the debate rumbled on. The year book shows a surprisingly large proportion of classified catalogues; in many cases there is no reference to an author index, but it is hard to imagine that they did not exist, and perhaps this was assumed. Ormerod recommends the dictionary catalogue (on cards) for a branch library because the user does not have to consult it twice for the subject he is looking for. He points to the fact that most American public libraries have dictionary catalogues, something noted also by Sharp on a visit there shortly after. ${ }^{140}$ McClelland regarded the author and dictionary catalogues as being easier to use than the classified, and surprisingly felt that it was adequate to provide an index to the latter in the form of a published index to Dewey. ${ }^{141}$ He states that card catalogues, 'now the order of the day', must be clearly labelled, otherwise the borrowers would fail to recognize them as such. Cranshaw discusses the subject at some length, making the valid comparison between the printed and the card catalogue that it is much easier to scan a group of entries on the printed page. This leads him to conclude that for a classified arrangement cards are less satisfactory. He has no doubt that, although English librarians generally prefer the classified, 'for the users of municipal libraries' the dictionary form is best. ${ }^{142}$ Like Plant many years before, he recognized that classification schemes (especially Dewey) so often scatter material on the same subject, which is brought together in a dictionary catalogue. This point seems to have remained largely ignored by advocates of the classified catalogue.

Even during the War the old debate over dictionary or classified was continued in the pages of the Library Association Record, and the same arguments used on both sides. ${ }^{143}$ Freeman stated that of the eight public library systems of which he had experience only one used the dictionary catalogue, and this proportion is not surprising on the evidence of the year book. McColvin in 1942 found a wide variety of catalogues: card, sheaf, 
printed and guard books, and sometimes more than one of these in the same library; most were of poor quality. ${ }^{144} \mathrm{He}$ does not, however, provide enough detail to enable us to say how many printed catalogues still existed. There seems to have been no preference for any particular inner form either, and except in closed access libraries there was little evidence that catalogues were used by the public. He recommended setting up a national cataloguing department to avoid the duplication of work which was occurring.

\section{After the Second World War}

The year book for 1948 shows very few public libraries still with printed catalogues, most having changed to cards. Those surviving are mainly either very large authorities such as Bradford and Manchester, where a presumably existing printed catalogue was supplemented by cards, or very small ones such as Stornoway, where perhaps the printed catalogue was the same as that existing before the War. ${ }^{145}$ In I952 a survey (admittedly very selective) found no examples of printed catalogues in any municipal library, though it is mentioned that a revaluation of the merits of the printed catalogue was being undertaken. ${ }^{146}$ At the same time it appeared that in British universities printed catalogues were 'exceptional', though not unknown, and card catalogues were the commonest physical form.

In 1950 the long hoped for central cataloguing bureau was set up in the form of the British National Bibliography, and in 1956 it started to issue printed catalogue cards, which any library could purchase and file into its own catalogue. By the end of the year there were I60 subscribers. ${ }^{147}$ Not everyone found them convenient, however, and almost a decade later it was reported that very few London libraries were using BNB cards. This was partly because they were not available at the time they were needed, and partly due to the extent to which they required modification, though the latter aspect is not expanded upon. ${ }^{148}$ At Tower Hamlets it was found much more efficient to produce cards in-house, so that if books were selected on approval on a Monday they could be supplied to libraries, complete with catalogue cards, on the Friday. ${ }^{149}$ There was clearly still a demand for information on different ways of reproducing cards. ${ }^{150}$ Camden did not start using BNB cards until I972, when the I8th edition of Dewey was adopted and when it became possible to order cards without quoting the BNB number. ${ }^{151}$

'Redgauntlet' commented in I960 on the demise of the printed catalogue, saying that only 'great libraries such as Glasgow and Westminster' continued to provide them, but that they were widely bought by other libraries, which showed that they had more than local value. ${ }^{152}$ He states that in the United States opinion is moving in favour of the dictionary catalogue as being the best for the average reader, but if earlier evidence is to be believed this had been the case for some years.

In Greater London, the reorganization of the London boroughs which took effect on I April I965 had an impact on catalogues. Some authorities, such as Westminster, still had printed catalogues, while others used cards, and mergers meant that standardization had to take place. ${ }^{153}$ Bromley managed to combine the author catalogues of its four constituent authorities and 'by skilful editing and masking' to produce a union catalogue. ${ }^{154}$ A late example prior to computerization was a Liverpool catalogue of additions covering the years 1960-1963, reproduced from typed pages and published in I968. ${ }^{155}$ 


\section{The advent of computers}

As computers came into use for cataloguing, it was common in the early days for public libraries to make use of the facilities of their local authority, rather than acquiring their own systems. Thus computers were used to produce an annual, cumulated, printed catalogue of gramophone records at Luton, and in Wiltshire a subject catalogue was produced in the same way. ${ }^{156}$

Elsewhere the computer was seen as a possible means of facilitating the continuance or reintroduction of printed catalogues. The London Borough of Camden was formed in I965 by the amalgamation of Hampstead, Holborn and St Pancras, and a printed union catalogue was produced by computer, the author list being replaced every fortnight. ${ }^{157}$ Westminster had its catalogue printed out on a line-printer and then reduced to $\mathrm{A}_{4}$ and reproduced. ${ }^{158}$ Barnet Public Libraries found that they could produce a printed union catalogue by computer, but it was at the expense of detail. ${ }^{159}$ Each field could have only a fixed number of characters, so that only the first author was shown, together with title, often abbreviated, and the last two figures of the year of publication. The whole was set in capitals. There were also filing problems because in those early days it was impossible to change the way the computer filed numerals and special characters. For example, the full stop, apostrophe and hyphen all filed between I and J, and a space filed after numerals. All in all, the result is a far cry from the catalogues of the late nineteenth century. On the other hand, it allowed the authority to provide a union catalogue of its stock at every branch, and the catalogues took up very little space. At Camden it allowed the production of title sequences, which had not been possible before. ${ }^{160}$ Later, using MARC records, Birmingham Public Libraries on joining BLCMP had the catalogue for their branches produced in printed form. ${ }^{161}$

In the United States there was a considerable resurgence of interest in the book catalog' and many articles were written about how the computer could provide a means of its resurrection. ${ }^{162}$ In Britain there was clearly much less interest, and in any case by the I980s the online catalogue was beginning to appear in British libraries. West Sussex was unusual in that it continued to produce printed catalogues (in loose-leaf binders) until the late I990s, and the writer well remembers using these in his local library. Unfortunately none of them have been preserved."163

\section{Special uses}

As a postscript, it is worth noting that printed catalogues survive for special collections which are not subject to much change. Manchester Public Libraries, for example, published their catalogue of private press books in I959/60, at a time when it would have been very unusual otherwise to print a catalogue. ${ }^{164}$ Collison, writing at a time when the production of such special catalogues was at its height, provides a comprehensive subject guide. ${ }^{165}$ Nowadays the production of such specialized catalogues would be unusual; an example is the Wellcome Library, which has continued to publish its Catalogue of printed books in volumes, though this does not cover recent publications. ${ }^{166}$

Now that we have online catalogues and most of them are available to remote users via the internet, we have come full circle because borrowers can once again consult the catalogue in their homes, as they could in the days of the printed catalogue. 
It would be wrong to conclude without mentioning the other great, though posthumous, advantage of the printed catalogue, which is that it forms a permanent record of what was once in particular collections. Social and literary historians can gain some appreciation of reading habits, and library historians can learn something of how libraries were arranged and classified at particular times. All of this information is irrecoverable from a card, sheaf, or online catalogue, so that a historian of the future wishing to find out what was in our libraries in the early years of the twenty-first century will have a very difficult task.

${ }^{1}$ I use the term 'printed catalogue' throughout, to mean a catalogue, irrespective of arrangement, in printed book form. In the United States the term 'book catalog' seems to be more normal for this, but I feel that it is ambiguous, and the term 'printed catalogue' is used invariably throughout the British literature.

2 See J. Ranz, The printed book catalogue in American libraries: 1723-1900 (Chicago: American Library Association, 1964).

${ }^{3}$ Ranz, The printed book catalogue, 76-77.

${ }^{4}$ That the situation in reference libraries was much the same fifty years later is shown by J. D. Brown, The reference library, Library World 3 (I900/OI) 20I-05.

${ }^{5}$ F. T. Barrett, The alphabetical and classified forms of catalogues compared, Transactions and proceedings of the Second International Library Conference, held in London ... I897 (London: Printed for members of the Conference, I898) 67-7I.

${ }^{6}$ D. M. Norris, A history of cataloguing and cataloguing methods: II00-I850: with an introductory survey of ancient times (London: Grafton, 1939) 228.

7 J. Henry Quinn, Library cataloguing (London: Truslove \& Hanson, I9I3) I2-I3.

8 T. Greenwood, Public libraries: a history of the movement and a manual for the organization and management of rate-supported libraries, $4^{\text {th }}$ edn (London: Cassell, I89I) 405. The preface attributes this section to Brown.

9 See J. D. Brown, Classification and cataloguing, The Library 9 (I897) I43-56.

${ }^{10}$ For a brief general history of the classified catalogue, see H. A. Funnell, A sketch of the history of the classified catalogue in the British Isles, Library World I4 (I9II/I2) I97-200.

${ }^{11}$ L. Stanley Jast, What the classified catalogue does, Library World I (I898/99) 2I3-I5.

12 J. Pettee, Subject headings: the history and theory of the alphabetical approach to books (New York: H. W. Wilson, I946) 37.

${ }_{13}^{13}$ H. E. Curran, Acceptable free library catalogues, The Library 7 (I895) 2 I-28.

${ }^{14}$ L. Stanley Jast, Classification in public libraries: with special reference to the Dewey Decimal System, The Library 7 (I895) I69-78.

${ }^{15}$ Recent catalogues, The Library 7 (1895) I88-90.

${ }^{16}$ L. Stanley Jast, The class list, The Library 9 (I897) 4I-44.

${ }_{17}$ Barrett, Alphabetical and classified forms compared. Also reported in The Library 9 (I897) 290.

${ }_{18}$ W. E. Doubleday, Class lists, or dictionary catalogues?, The Library 9 (I897) I78-89.

19 J. Henry Quinn, Manual of library cataloguing (London: Library Supply Co., I899) I3.

${ }^{20}$ L. Stanley Jast, Classified versus dictionary cataloguing, Library World I (I898/99) I59-62.

${ }^{21}$ Reported in Library World I (1898/99) 238-39. The account does not mention the discussion following.

22 J. Duff Brown, The reference library, Library World 3 (I900/OI) 20I-05.

23 W. J. Willcock, Classed catalogues \& their indexes, Library World 3 (I900/oI) 26I-62.

${ }^{24} \mathrm{H}$. Bond, Classified versus dictionary: a comparison of printed catalogues, Library Association Record 2 (I900) 3I 3 -I 8 .

${ }_{25}$ J. Henry Quinn, Dictionary catalogues versus classified catalogues for public libraries. The classified catalogue, The Library 3 (I90I) 5I4-20.

${ }^{26}$ W. E. Doubleday, Dictionary catalogues versus classified catalogues for public libraries. The dictionary catalogue, The Library 3 (I90I) 52I-3I.

27 W. C. Plant, Disputed points in cataloguing, Library Association Record 5 (I903) 225-37.

${ }^{28}$ Library Association Record 5 (I903) 254.

29 W. S. C. Rae, Popularising the best books, Library Association Record 5 (1903) 623-29.

30 T. Greenwood (ed.), Greenwood's library year book I897 (London: Cassell, I897). Next edition was entitled: British library year book I900-I90I (London: Scott, Greenwood, I900). Subsequently this became Libraries, museums and art galleries year book and it still exists as The libraries directory. The Literary year-book and bookman's directory (London: Routledge, and other later publishers) showed details of libraries for a few years between about 1907 and I9I4. 
31 Airdrie, Bangor, Carnarvon, Ealing, Eastbourne, Grangemouth, Grays, Hove, Leicester, Luton, Macclesfield, Middle Claydon, Middlewich, Sowerby Bridge, Stafford, Walsall, Winchester, Wood Green, Wrexham.

${ }^{32}$ E.g. 'with the coming of shelf classification came the classified catalogue', H. A. Sharp, Cataloguing: a textbook for use in libraries, 2nd edn (London: Grafton, I937) 32.

33 Borough of Aston Manor, Catalogue of the central lending department of the Aston Manor Public Library: arranged on the dictionary plan (Aston Manor, I906).

34 J. Duff Brown, The tyranny of the catalogue, Library World II (I908/09) I-6.

35 Sheaf only: Evesham, Halifax, Islington, Kettering, Malvern, Rathmines, St Albans. Card only: Exeter, Farnworth, Folkestone, Goole, Govan, Grays, Hove, Kingston-upon-Thames, Luton, Maidenhead, Newbury, Northampton, Shipley, Stockport, Teddington, Twickenham, Worthing. Several others 'manuscript' but undefined.

36 J. Douglas Young, Are printed catalogues desirable for open-access libraries?, Library Assistant I47 (April I9Io) I23-29.

${ }^{37}$ W. C. Berwick Sayers, Is the printed catalogue desirable for open access libraries?, Library Assistant I5I/I52 (August/September I9IO) 209-I3.

${ }^{38}$ Metropolitan Borough of Islington, Public Libraries, Select catalogue and guide: a classified list of the best books on all subjects in the central, north and west libraries (Islington, I9IO).

${ }^{39}$ L. Stanley Jast, A novel catalogue, Library World I3 (I9Io/II) I93-96.

40 Islington, Select catalogue, 4.

41 G. T. Shaw, Open access: an experiment, Library Association Record I5 (I9I3) I9.

42 A. J. Philip, The production of the printed catalogue (London: Robert Atkinson, I9IO).

43 Philip, The production of the printed catalogue, I6-I7.

44 Introduction to Open access libraries: their planning, equipment and organisation, J. Douglas Stewart ... [et al.] (London: Grafton, I9I5).

45 W. McGill and H. T. Coutts, Special catalogues in Open access libraries, I48.

46 W. Lillie, The merits of the classified and dictionary catalogues, Library World I7 (I9I4/I5) 97-IO2.

${ }^{47} \mathrm{H}$. Bond, Some features of recent library practice in Great Britain, Library Association Record I7 (I9I5) 227-43.

48 Library World I9 (I9I6/I7) $3 \mathrm{I}$.

49 Recent catalogues, The Library 7 (I895) I88-92.

${ }^{50}$ Library World 6 (I903/04) 298-99.

51 J. J. Ogle, Some pitfalls in cataloguing, The Library 8 (I896) I5 I-56.

52 Recent catalogues, The Library 7 (I895) I88-92.

53 See P. Sturges and A. Barr, 'The fiction nuisance' in nineteenth-century British public libraries, Journal of librarianship and information science 24 (I992) $23-32$.

54 Library Association Record 5 (I903) $25 \mathrm{I}$.

55 Review of supplementary catalogue issued 1904, Library Association Record 7 (I905) I86.

56 Saint George, Hanover Square, Public Libraries, Catalogue of books in the lending department ... (London: Printed for the Public Libraries Commissioners, I894), 39-4I.

${ }^{57}$ L. Stanley Jast, Classified and annotated cataloguing: the individual biographical entry, Library World 3 (I900/OI) 29-3I.

${ }_{58}$ H. G. Steele, A note on alphabetical order, Library World I5 (I9I2/I3) $247-48$.

59 A. J. Hawkes, The alphabetization of catalogues, Library World I5 (I9I2/I3) $262-66$.

${ }^{60}$ J. Cranshaw, A word or two, Library Assistant 29:444 (November I936) 259-63.

${ }^{61}$ L. Stanley Jast, Classified and annotated cataloguing: suggestions and rules, Library World 2 (I899/I900) II8-2I.

${ }^{62}$ G. T. Shaw, Is it necessary to print in reference library catalogues lists of the contents of the publications of learned societies?, Library Association Record 4 (I902) 583-89.

${ }^{63}$ C. A. Cutter, Rules for a dictionary catalog, 3rd edn (Washington, DC: GPO, I89I) 70-72.

${ }^{64}$ Quinn, Library cataloguing, I3.

65 Ogle, Some pitfalls in cataloguing, I53.

66 J. D. Brown and L. Stanley Jast, The compilation of class lists, The Library 9 (I897) 53.

67 J. D. Brown, Classification and cataloguing, The Library 9 (I897) I53.

68 A. Crestadoro, Catalogue of books in the Manchester Free Library, reference department (London: Sampson, Low, I864).

69 Ogle, Some pitfalls in cataloguing, I55.

${ }^{70}$ Examples: Gorbals District Library, Library World 5 (I902/03) 69 ('the best public library catalogue we have seen for years'); Woodside District Library, Library World 8 (I905/06) I64.

71 E. Green, The old order and the new, Library World 4 (I901/02) 39.

${ }^{72}$ E. A. Savage, Manual of descriptive annotation for library catalogues (London: Library Supply Co., I906); W. C. Berwick Sayers, First steps in annotation in catalogues (London: Association of Assistant Librarians, I9I8).

73 Both aspects mentioned in review of catalogue of Handsworth Public Libraries, I904, Library Association Record 6 (I904) 632.

${ }^{74}$ Brown and Jast, Compilation of class lists. 
5 Newcastle-upon-Tyne Public Libraries, Catalogue of books in the useful arts compiled by B. Anderton (Newcastle, I903).

${ }^{76}$ Review in Library World 6 (1903/04) 298.

77 Diogenes the Tub-Thumper, The dangers of dictionary cataloguing, Library World 4 (I90I/O2) 270-72.

${ }^{78}$ Library World 4 (1901/02) 162-63.

79 Both reviews in Library World 5 (I902/03) 2I2-I4.

${ }^{80}$ Reviewed in Library World 5 (1902/03) 70.

${ }^{81}$ Library World 5 (I902/03) $2 \mathrm{I} 4$.

82 E. A. Savage, The new Hampstead catalogue, Library World 8 (I905/06) 32I-22.

${ }^{83}$ Library World 2 (I899/I900) II 2.

${ }^{84}$ A. W. Robertson, Aberdeen Public Library, The Library 9 (I897) 99.

${ }^{85}$ Brown and Jast, Compilation of class lists, $\overline{46-47}$.

${ }^{86}$ Quinn, Dictionary catalogues versus classified catalogues, 5 I 7 .

${ }^{87}$ Brown, The tyranny of the catalogue, 6.

${ }^{88}$ A. Capel Shaw, The Birmingham free libraries, Library Association Record 4 (I902) 508.

${ }^{89}$ R. W. Mould, Some library aids - other than mechanical, Library Association Record 5 (1903) 363.

${ }^{90}$ Library Association Record I (I899) 602.

91 Philip, The production of the printed catalogue, 36.

92 E. A. Savage, A librarian's memories: portraits \& reflections (London: Grafton, 1952) 98-99.

${ }_{93}$ R. A. Peddie, The Decimal Classification and relative location, The Library 9 (I897) 349.

${ }_{94}$ E. Green, Recollected in tranquillity, Library Review 7 (I939/40) 328.

95 E. A. Baker, The compilation of a complete card catalogue from old printed catalogues, Library World I (I898/99) I4I-42.

96 T. Aldred, The Linotype in catalogue printing, Library World I (I898/99) 226-27.

97 The Linotype in catalogue printing (letter), Library World 2 (I899/1900) 28.

${ }_{98}$ Letter from H. Bond, Library Association Record I (I899) 8I6.

99 Reviewed in Library Association Record 2 (1900) I62-63.

100 W. E. Doubleday, A new method of printing catalogues, Library World 5 (I902/03) 28I-83 and 309-I2.

101 Jast, The class list, 42.

102 T. E. Maw, The card catalogue as a substitute for the printed catalogue, Library World 2 (I899/1900) 63-68.

${ }^{103}$ Green, The old order, 4I.

${ }^{104}$ See for example Library World 5 (I902/03) v-vii of April I903 issue, and elsewhere. The Library Supply Co. used the slogan 'The life of a card catalogue never ends'; several examples in Library Association Record I (I899).

105 Library Association Record 3 (I90I) 227.

106 W. J. Willcock, Is the printed catalogue doomed?, Library Association Record 9 (I907) 384-89.

107 Library World I3 (I9IO/II) 242. The catalogue dated from I89I.

108 W. C. Berwick Sayers and J. D. Stewart, The card catalogue, Library World I4 (I9II/I2) I62-65, 205-II, 236-39, 265-70, 290-98, 325-29, 358-64; I5 (I9I2/I3) 38-45, 77-83, I07-IO; and The card catalogue: a practical manual for public and private libraries (London: Grafton, I9I3).

109 E. Crowther, A combined indicator and card catalogue, Library World I (I898/99) I70-72. The indicator was the contrivance by which in most libraries the borrowers were able to ascertain whether a book was in or out.

110 J. D. Stewart, The sheaf catalogue, Library World Io (I907/08) 4I-44, 85-88, I23-28, 204-06, 28I-83, 364-67; II (1908/09) I5-I7, I36; and The sheaf catalogue: a practical handbook on the compilation of manuscript catalogues for public and private libraries (London: Libraco, 1909).

111 L. Stanley Jast, The sheaf and card catalogues: a comparison, Library World 5 (1902/03) I29-3I.

112 J. Ormerod, The Rand visible index, Library Association Record I7 (I9I5) I8-23.

113 See W. J. Plumbe, The 'Stripdex' catalogue, Library Association Record 64 (I962) I28-3I.

114 G. Vine, On the construction of the subject-catalogue, Library Association Record II (I909) 489.

115 Sayers, for example, speculates whether even $5 \%$ of borrowers buy catalogues: W. C. Berwick Sayers, Is the printed catalogue desirable for open access libraries?, Library Assistant I5I/2 (August/September I9IO) 2 II.

116 Catalogues and other printed aids: a symposium by county librarians, Library Review 5 (1935/36) 355 .

117 Note in Library World I9 (1916/17) 3I.

118 Library World I3 (I9IO/II) 2 II.

119 H. A. Sharp, Cataloguing: a textbook for use in libraries, 2nd edn (London: Grafton, 1937) I72-73.

120 R. Wright, Co-operative cataloguing [Part 2], Library World 26 (1923/24) Io.

121 A. S. Cooke, Kent County Library, Library Review 2 (1929/30) 77.

122 Catalogues and other printed aids, 355 .

${ }^{123}$ Library Review 2 (1929/30) 43.

124 Library Review I (1927/28) IO2.

125 Library Review I (I927/28) 294. Reviewed in Library Assistant 2I (I928) 222, where it was described as 'probably the most extensive piece of printed cataloguing yet produced by the county libraries'. 
${ }_{126}$ Mrs A. Henderson, County library cataloguing, Library World 33 (I930/3I) II8.

127 Library Review 2 (I929/30) 334.

${ }^{128}$ Library Review 2 (1929/30) I62.

129 Library Review 2 (I929/30) 219.

${ }_{130}$ Some tendencies, Library Assistant 24 (I93I) 56.

131 Rochdale Public Libraries, Catalogue of books in the central lending library (Rochdale, published in sections, I927-I934). A brief note of the 5 th appears in Library World 3 (1930/3I) 242-43.

132 Library Assistant 24 (I93I) II 5 -I6.

133 W. C. Berwick Sayers, Some catalogue problems, Library World 33 (1930/3I) 307-I2.

${ }^{134}$ Catalogues and other printed aids. Middlesex had by 1928 produced such selective lists for Economics and History (reviewed in Library Assistant 2I [1928] I72).

135 The counties where only printed catalogues are mentioned are Caernarvonshire, Dorset and the Isle of Wight. In certain other cases a printed catalogue was probably supplemented by cards, and in a few cases the entry is ambiguous.

${ }_{136}$ Catalogues and other printed aids: a symposium of municipal librarians, Library Review 6 (I937/38) 22.

${ }^{137}$ Ibid., 25. In any case the Libraries, museums and art galleries year book for I937 shows Bethnal Green as having a card catalogue.

${ }^{138}$ H. A. Sharp, Cataloguing: a textbook for use in libraries (London: Grafton, I937) I72; J. D. Brown, Manual of library economy 5 th edn, by W. C. Berwick Sayers (London: Grafton, I937) 268.

${ }_{139}$ Library Review 8 (194I/42) 34-35.

140 J. Ormerod, Branch libraries, Library World 33 (I930/3I) 262. Sharp, Cataloguing, 29.

141 W. R. McClelland, Guidance for readers, Library Assistant 29:442 (September I936) I95.

142 J. Cranshaw, The public and the catalogue: dictionary or classified?, Library Assistant 30 (1937) $72-78$.

${ }_{143}$ C. B. Freeman, The classified catalogue: a plea for its abolition in public libraries, Library Association Record 44 (I942) I47-50; B. I. Palmer, The classified catalogue: a reply to Mr. C. B. Freeman, Library Association Record 46 (1944) 59-60; letter from C. B. Freeman, Library Association Record 46 (1944) 92.

${ }^{144}$ L. R. McColvin, The public library system of Great Britain: a report ... (London: Library Association, I942) $83-84$.

145 The complete list for 1948 is: Ashton-in-Makerfield (sheaf also), Bo'ness, Bradford (card also), Dumbarton ('manuscript' also), Larne, Manchester (card also), Middle Claydon (guard book also), Stornoway (in sections). In several other cases the information is missing, and in other respects this is incomplete. We know, for example, that Westminster still had a printed catalogue.

${ }_{146}$ M. Piggott (ed.), Cataloguing principles and practice: an inquiry (London: Library Association, I954) I47.

${ }^{147}$ Library Association Record 59 (I957), letter from A. J. Wells.

148 W. S. H. Ashmore, Cataloguing, classification and book provision in the new London boroughs, Assistant Librarian 59 (1966) 74-77.

149 F. Bennett, Mergers and catalogues, Library Association Record 70 (I968) IоI.

${ }^{150}$ For example, F. Liebesny, A new method for duplicating catalogue cards, Library Association Record 59 (I957) 403; P. S. Pargeter, The reproduction of catalogue cards (London: Library Association, I960).

${ }_{151}$ R. Payne, Use if BNB cards in Camden, Catalogue \& Index 33 (Spring 1974) 9-10.

${ }^{152}$ Library Review I7 (1959/60) 598-9.

${ }^{153}$ K. C. Harrison, A librarian's odyssey: episodes of autobiography (Eastbourne: The author, 2000) 27.

${ }^{154}$ Amalgamation and after, Assistant Librarian 59 (1966) 72.

${ }^{155}$ K. R. Kirby, Catalogues, in H. A. Whatley (ed.), British librarianship and information science 1966-1970 (London: Library Association, I972) 86.

${ }^{156}$ H. Hammond, A punched card gramophone record catalogue at Luton Central Library, Library World 68 (I966) 67) I68; Library World 67 (1965/66) 263.

157 The computer catalogue in Camden, Library World 67 (1965/66) 40. See also W. R. Maidment, Librarianship (Newton Abbot: David \& Charles, I975) I38.

${ }_{158}$ Illustrated in J. Eyre and P. Tonks, Computers \& Systems (London: Bingley, I97I) I2I.

159 A. O. Meakin, The production of a printed union catalogue by computer, Library Association Record 67 (I965) 3II-I6. A specimen page is reproduced.

${ }_{160}$ See: Better cataloguers for worse catalogues, Catalogue \& Index 3 (I966) I and 8.

${ }^{161}$ R. T. Kimber, Mechanization in libraries, in H. A. Whatley (ed.), British librarianship and information science I97I-1975 (London: Library Association, I977) 26. These catalogues were loose-leaf and were introduced in I972; they were soon superseded by microfiche and no examples survive (information from Pam Garbett, Bibliographic Services, Birmingham, email, 20 January 2005).

${ }_{162}$ See for example M. F. Tauber and H. Feinberg (eds.), Book catalogs (Metuchen, NJ: Scarecrow Press, I97I).

163 Information from Alan Goodman, Marketing \& Customer Services Manager, West Sussex County Libraries (email, I6 December 2004). 
164 Manchester Public Libraries, Reference Library subject catalogue section 094: private press books (Manchester: Libraries Committee, I959 and I960).

${ }_{165}$ R.T. Collison, Published library catalogues: an introduction to their contents and use (London: Mansell, I973). 166 Wellcome Historical Medical Library, A catalogue of printed books in the Wellcome Historical Medical Library (London: Wellcome Historical Medical Library, I962-I995 so far). 